\title{
Multiproxy evidence of Holocene climate variability from estuarine sediments, eastern North America
}

\author{
T. M. Cronin, ${ }^{1}$ R. Thunell, ${ }^{2}$ G. S. Dwyer, ${ }^{3}$ C. Saenger, ${ }^{1}$ M. E. Mann, ${ }^{4,5}$ C. Vann, ${ }^{1}$ \\ and R. R. Seal II ${ }^{1}$ \\ Received 14 February 2005; revised 19 May 2005; accepted 8 July 2005; published 19 October 2005.
}

[1] We reconstructed paleoclimate patterns from oxygen and carbon isotope records from the fossil estuarine benthic foraminifera Elphidium and $\mathrm{Mg} / \mathrm{Ca}$ ratios from the ostracode Loxoconcha from sediment cores from Chesapeake Bay to examine the Holocene evolution of North Atlantic Oscillation (NAO)-type climate variability. Precipitation-driven river discharge and regional temperature variability are the primary influences on Chesapeake Bay salinity and water temperature, respectively. We first calibrated modern $\delta^{18} \mathrm{O}_{\text {water }}$ to salinity and applied this relationship to calculate trends in paleosalinity from the $\delta^{18} \mathrm{O}_{\text {foram }}$, correcting for changes in water temperature estimated from ostracode $\mathrm{Mg} / \mathrm{Ca}$ ratios. The results indicate a much drier early Holocene in which mean paleosalinity was $\sim 28 \mathrm{ppt}$ in the northern bay, falling $\sim 25 \%$ to $\sim 20 \mathrm{ppt}$ during the late Holocene. Early Holocene $\mathrm{Mg} / \mathrm{Ca}$-derived temperatures varied in a relatively narrow range of $13^{\circ}$ to $16^{\circ} \mathrm{C}$ with a mean temperature of $14.2^{\circ} \mathrm{C}$ and excursions above $16^{\circ} \mathrm{C}$; the late Holocene was on average cooler (mean temperature of $12.8^{\circ} \mathrm{C}$ ). In addition to the large contrast between early and late Holocene regional climate conditions, multidecadal (20-40 years) salinity and temperature variability is an inherent part of the region's climate during both the early and late Holocene, including the Medieval Warm Period and Little Ice Age. These patterns are similar to those observed during the twentieth century caused by NAO-related processes. Comparison of the midlatitude Chesapeake Bay salinity record with tropical climate records of Intertropical Convergence Zone fluctuations inferred from the Cariaco Basin titanium record suggests an anticorrelation between precipitation in the two regions at both millennial and centennial timescales.

Citation: Cronin, T. M., R. Thunell, G. S. Dwyer, C. Saenger, M. E. Mann, C. Vann, and R. R. Seal II (2005), Multiproxy evidence of Holocene climate variability from estuarine sediments, eastern North America, Paleoceanography, 20, PA4006,

doi:10.1029/2005PA001145.

\section{Introduction}

[2] The patterns and causes of submillennial-scale Holocene climate variability, the context for understanding twentieth century climate, are still only partially understood. In the tropics, evidence from paleoclimate reconstructions of El Niño-Southern Oscillation (ENSO) suggests increasing frequency and amplitude of ENSO variability during the late Holocene, which some authors attribute to changes in solar insolation [Clement et al., 2000; Rodbell et al., 1999; Sandweiss et al., 2001; Riedinger et al., 2002; Gomez et al., 2004]. In extratropical regions, the long-term evolution of the North Atlantic Oscillation (NAO), the primary mode of climate variability in the North Atlantic region is not so clear [Hurrell, 1995; Hurrell et al., 2003]. The NAO is

\footnotetext{
${ }^{1}$ U.S. Geological Survey, Reston, Virginia, USA.

${ }^{2}$ Department of Geological Sciences, University of South Carolina, Columbia, South Carolina, USA.

${ }^{3}$ Nicholas School of the Environment, Earth and Ocean Sciences, Duke University, Durham, North Carolina, USA.

${ }^{4}$ Department of Environmental Science, University of Virginia, Charlottesville, Virginia, USA.

${ }^{5}$ Now at Department of Meteorology, Pennsylvania State University, University Park, Pennsylvania, USA.
}

Copyright 2005 by the American Geophysical Union. 0883-8305/05/2005PA001145 defined as a north-to-south oscillation of atmospheric mass centered on the Azores high-pressure and Icelandic lowpressure systems. During the positive (negative) phase of the NAO, there is an increased (decreased) pressure gradient between the Azores and Icelandic systems, causing warmer (cooler) and wetter (drier) mean winter conditions in Europe and the eastern United States (Figure 1). Although interannual NAO variability observed in instrumental records shows no distinct periodicity, and may be driven by stochastic internal atmospheric processes [Wunsch, 1999; Czaja et al., 2003], atmospheric, oceanic, and modeling studies suggest that multidecadal patterns $(\sim 60-70$ years $)$ might characterize the NAO [Schlesinger and Ramankutty, 1994; Dickson et al., 1996; Delworth and Mann, 2000]. Late Holocene paleorecords of NAO-type variability from tree rings, ice cores, sediments and molluscan isotopes, some combined with instrumental data, provide strong evidence for multidecadal climate variability in the North Atlantic region [Cook et al., 1998, 2002; Cook, 2003; Appenzeller et al., 1998; Cullen et al., 2001; Luterbacher et al., 2004; Kirby et al., 2002; Schöne et al., 2003; Cronin et al., 2003]. However most paleorecords of NAO variability extend back only a few centuries, and no clear picture of multidecadal variability during the early Holocene has emerged. Here we present oxygen and carbon isotope and magnesium/calcium $(\mathrm{Mg} / \mathrm{Ca})$ records from calcareous 


\section{High-Low NAO Index Years}

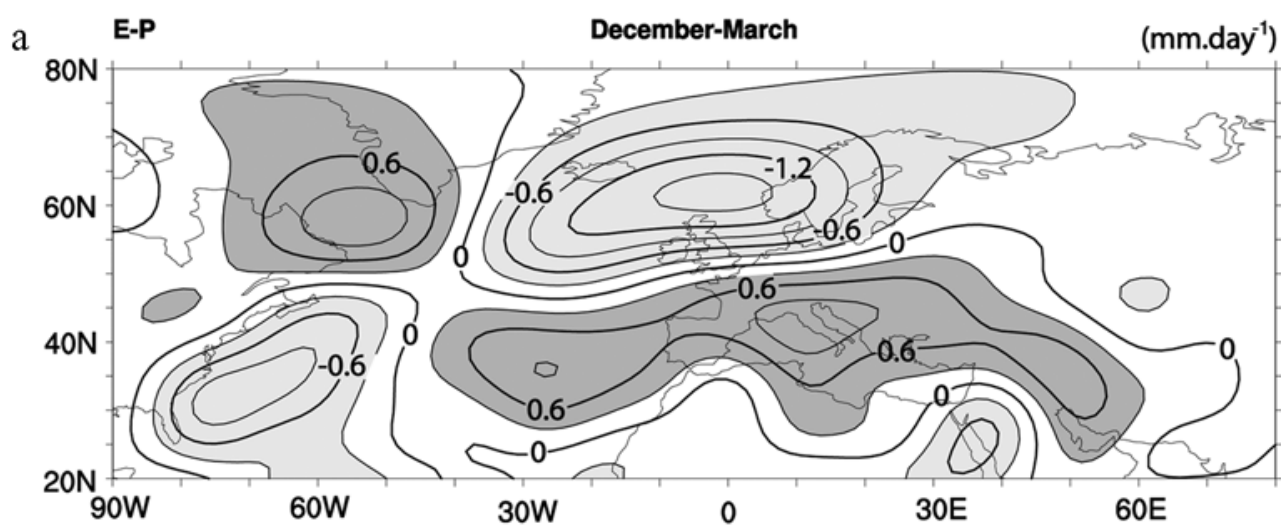

NAO Index, Surface Temperature

b December-March $\left(\times 10^{-1}{ }^{\circ} \mathrm{C}\right)$

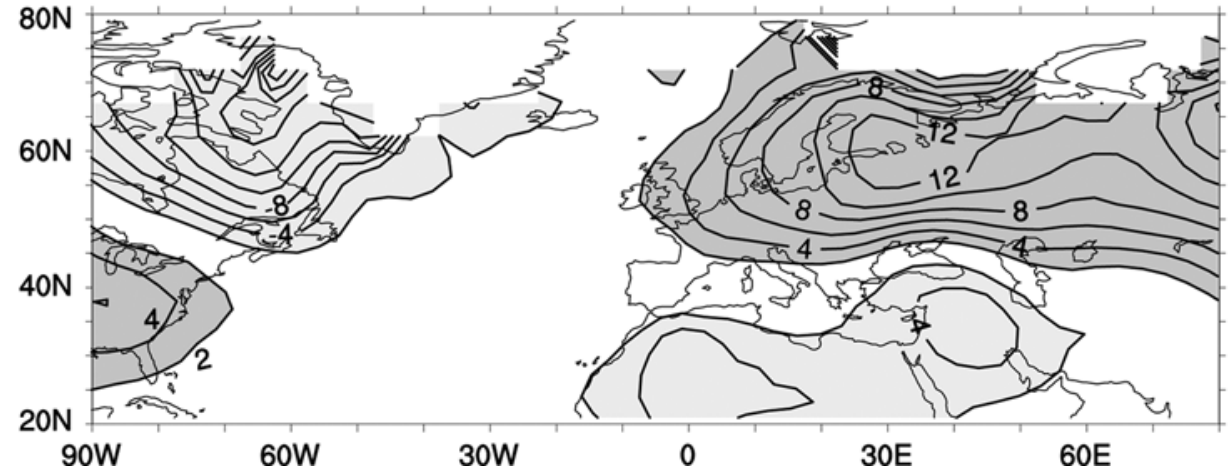

Figure 1. Map showing winter (December through March) precipitation and temperature anomalies associated with the North Atlantic Oscillation (NAO) in North Atlantic Region and location of Chesapeake Bay. (a) Differences in mean winter evaporation (E) minus precipitation (P) between years when NAO exceeds 1 standard deviation for period 1958-2001. E-P field is residual of atmospheric moisture budget as discussed by Hurrell [1995] based on National Centers for Environmental Prediction/ National Center for Atmospheric Research (NCEP/NCAR) reanalyses from 1958 to 2003. Contours are $0.3 \mathrm{~mm} \mathrm{~d}^{-1}$. Light shaded area over Chesapeake Bay region reflects precipitation exceeding evaporation during positive phase of NAO. (b) Change in mean winter land and sea surface temperature (times $10^{-1}$ ${ }^{\circ} \mathrm{C}$ ) corresponding to a unit deviation of NAO index for the period $1900-2002$. Contours are $0.2^{\circ} \mathrm{C}$; dark shading shows temperature changes $>0.2^{\circ} \mathrm{C}$. Modified from Hurrell et al. [2003], courtesy of J. Hurrell and A. Phillips (NCAR).

microfossils obtained from high sedimentation rate estuarine sediments from Chesapeake Bay to compare NAO-like precipitation and temperature changes during the early $(7.1-5.9 \mathrm{ka})$ and late $(2.2 \mathrm{ka}-$ present $)$ Holocene along the eastern United States. We also discuss these results in terms of broader patterns of Holocene climate in the North Atlantic region.

\section{Modern Climatology, Hydrology, and Estuarine Processes}

[3] Estuaries represent an untapped source of highresolution paleoclimate records because of their high sedimentation rates, which range from 0.1 to $>1 \mathrm{~cm} \mathrm{yr}^{-1}$ in Chesapeake Bay, and their sensitivity to decadal to centennial changes in precipitation, river discharge, and estuarine salinity. Chesapeake Bay, the largest estuary in the United States, is located in the Mid-Atlantic region of North America and experiences seasonal, interannual and low-frequency salinity variability controlled by freshwater discharge from its major tributaries (Figure 2). As a partially mixed estuary, density-driven circulation processes caused by the mixing of inflowing fresh water in the north and marine water in the south generally dominate over the influence of wind, tides and topography over interannual and decadal timescales [Boicourt et al., 1999]. Density-driven circulation dominates especially during winter season in the northern bay where the Susquehanna River, the dominant source of fresh water in the bays northern watershed, discharges more than $50 \%$ of the total freshwater input into the bay, $\sim 300 \mathrm{~km}$ from the marine source at the bay mouth [Schubel and Pritchard, 1986]. 


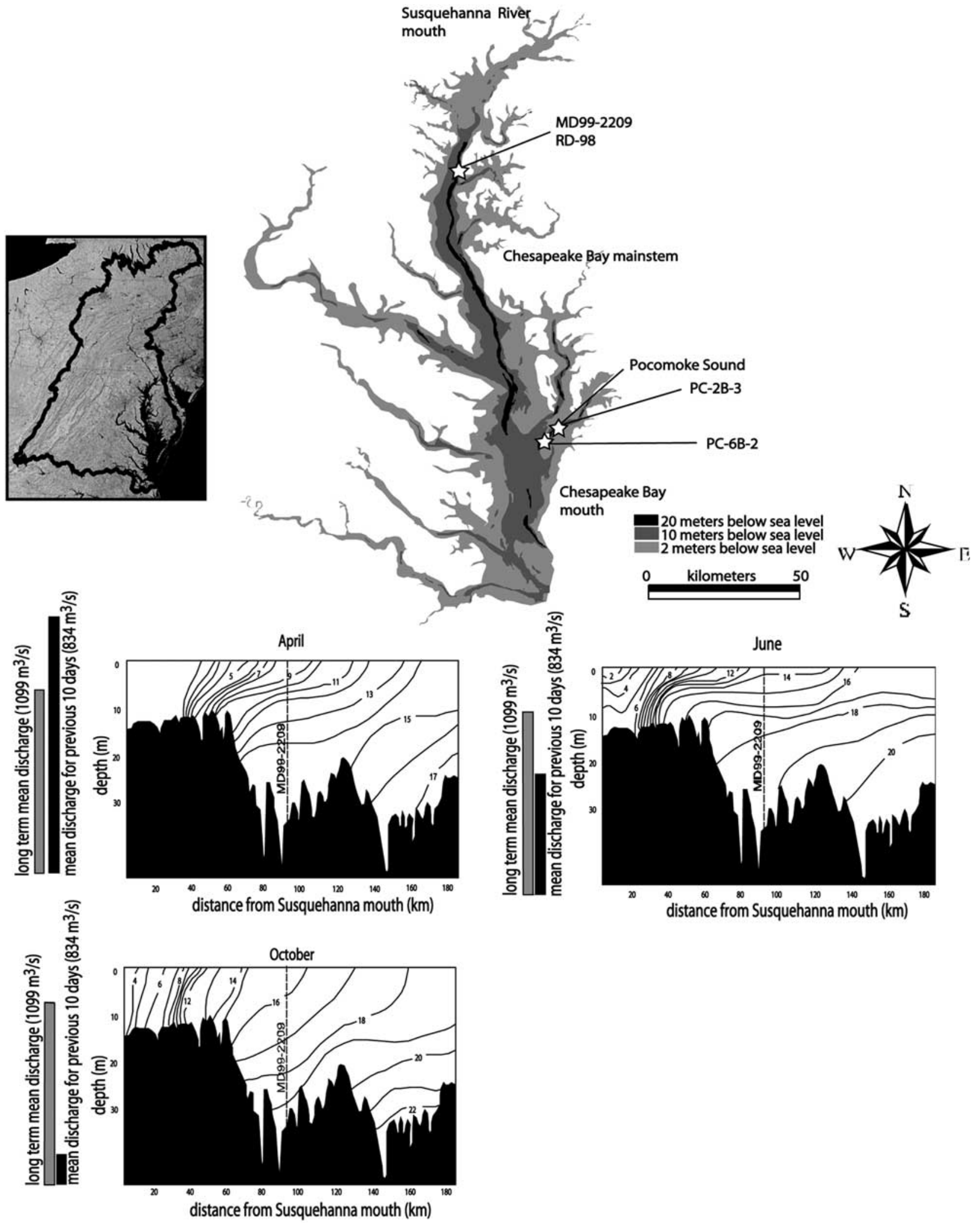

Figure 2. (top) Map showing core locations in Chesapeake Bay. Deep channel of main stem bay $>20 \mathrm{~m}$ water depth shown in dark shading. (bottom) Salinity gradients in the bay influenced mainly by freshwater runoff from Susquehanna River discharge. Chesapeake watershed is outlined in inset on left (U.S. Geological Survey map). 
[4] The relationships between modern bay salinity, freshwater discharge, precipitation, and atmospheric indices of the NAO and ENSO have been well established and are summarized as follows. Yarnal and Leathers [1988] showed that Susquehanna River discharge is critically sensitive to jetstream flow and regional precipitation. Precipitation and river discharge are dependent on the position of the atmospheric trough in the eastern United States, which oscillates over various timescales between meridional and zonal flow. Najjar [1999] developed a water balance model for the Susquehanna River Basin and showed that Susquehanna streamflow and regional precipitation are highly correlated $\left(\mathrm{r}^{2}=0.89\right)$ based on instrumental records covering the twentieth century. Gibson and Najjar [2000] then developed an autoregressive model to examine the relationship between Susquehanna River discharge and bay salinity. Depending on the location in the bay, the model captures up to $93 \%$ of the salinity variability when forced by Susquehanna River discharge. The Gibson/Najjar model predicts that a $32 \%$ increase in annual discharge would lead to a $55 \mathrm{~km}$ recession of isohalines in the middle bay. Salinity variability on this scale exceeds that observed over seasonal timescales (i.e., Figure 2) but is very similar to the magnitude of Holocene salinity changes reconstructed from the isotope records discussed below.

[5] A link between estuarine circulation, salinity, and NAO forcing of regional climatology of the eastern United States also has been demonstrated. Spatial data sets of the entire North Atlantic show that relatively warm and wet conditions existed off the eastern North America during the positive phase of NAO [Hurrell, 1995; Kapala et al., 1998]. Vega et al. [1998] examined regional climatology and showed that the NAO dominates interdecadal precipitation in the northern parts of the bay's watershed. Vega et al. [1999] then showed that density-driven circulation and salinity in Chesapeake Bay are governed by low-frequency (decadal) atmospheric processes associated with the NAO through their influence on regional precipitation and discharge. In brief, these studies show that the positive (negative) phase of NAO is characterized by more zonal (meridional) flow, greater (less) storm frequency, and below (above) average salinity.

[6] Although the NAO is a primary influence on the climatology of the region, the influence of ENSO in the mid-Atlantic region must also be considered a factor in regional climatology. Several studies suggested at least a modest teleconnection between SOI and east coast precipitation [Ropelewski and Halpert, 1986; Montroy, 1997], and Vega et al. [1999] reported that increased Chesapeake Bay surface salinity corresponds with the negative phase of the SOI suggesting a potential influence of ENSO during the Holocene.

[7] Water temperature in Chesapeake Bay is influenced by inflowing oceanic source water flowing south-southwest on the adjacent continental shelf, modified by atmospheric temperatures in the mid-Atlantic region. Bay water winter and summer temperature extremes $\left(\sim 1^{\circ}-2^{\circ}\right.$ and $25^{\circ}-26^{\circ} \mathrm{C}$, respectively) are greater than those on the shelf, but a strong positive correlation between seasonal and interannual bay and oceanic temperatures exists for the last 20 years of monitoring data (see below).

[8] In sum, salinity and temperature changes preserved in the bay's sedimentary record should provide an opportunity to examine long-term precipitation-related proxies in a region sensitive to the NAO, and perhaps also ENSO.

\section{Material and Methods}

[9] A thick sequence of Holocene estuarine sediments has been deposited in the main channel of Chesapeake Bay since the final phase of postglacial sea level rise occurred about 8 ka [Colman and Mixon, 1988; Vogt et al., 2000; Bratton et al., 2003a]. We obtained short (4-5 m) piston cores from the main stem of the central and northern bay in 1996-1998 and Pocomoke Sound in the southern bay region in 2001 during cruises of the R/V Kerhin [Kerhin et al., 1998; Baucom et al., 2001; Cronin, 2004]. These cores were supplemented with long Calypso piston cores (17-20 m) taken on the R/V Marion-Dufresne as part of the 1999 IMAGES cruise in the North Atlantic [Cronin, 2000]. Core locations include sites in the northern, central and southern regions of the bay representing modern mesohaline and polyhaline salinity regimes (Figure 2 and Table 1).

\subsection{Chronology}

[10] Our chronology is based on a combination of ${ }^{210} \mathrm{~Pb}$ and ${ }^{137} \mathrm{Cs}$ dating of twentieth century sediments, pollen stratigraphy tied to colonial land use changes [Willard et al., 2003; Cronin et al., 2003], and radiocarbon dating of estuarine mollusks and foraminifers [Cronin et al., 2000, 2003; Colman et al., 2002]. The previously published radiocarbon dates from these papers and new dates from the Pocomoke Sound region are given in Table 1. All radiocarbon dates were calibrated to calendar years using the Stuiver et al. [1998] CALIB program with a standard 400 -year marine correction. No correction for a regional carbon anomaly $(\Delta R)$ was applied because ${ }^{14} \mathrm{C}$ dates on oyster shells collected in the nineteenth and early twentieth centuries yielded a mean age of about 400 years, similar to the correction for marine reservoir effect [Colman et al., 2002]. In addition, sediments from the uppermost 50 to 300 $\mathrm{cm}$ of Chesapeake Bay were deposited during the colonial period $\sim$ A.D. $1750-1900$ and can easily be identified by the rising abundances of ragweed (Ambrosia) and grass (Poaceae) pollen, which serve as stratigraphic indicators of anthropogenic land clearance [Brush, 1984; Willard et al., 2003]. Radiocarbon dates of the bivalve Mulinia lateralis shells from peak Ambrosia horizons (A.D. 1880-1910) yield uncorrected ${ }^{14} \mathrm{C}$ ages averaging 461 years [Willard et al., 2005]. The expected age of these shells based on the tree ring chronology of Stuiver et al. [1998] would be $\sim 86$ years. Thus a mean total reservoir effect for Chesapeake Bay Mulinia is about 375 years, very close to the standard marine correction of 400 years. We assume there were no changes in the local reservoir effect during the last 7500 years.

[11] One short piston core and one Calypso core from a site in the north central bay, RD-98 and MD99-2209 (RD/ 2209 henceforth), provided the most detailed Holocene 


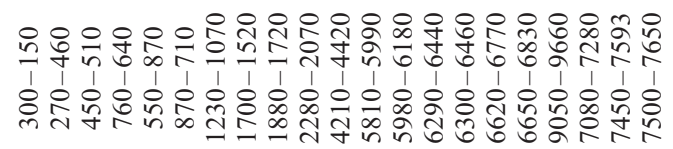

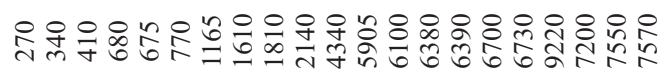

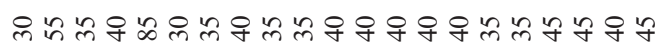

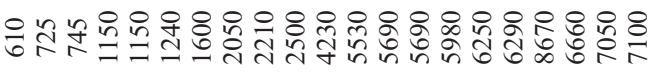

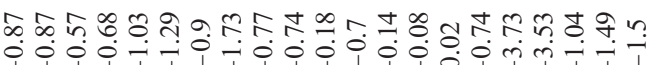

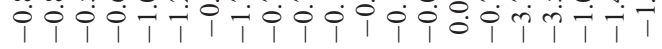

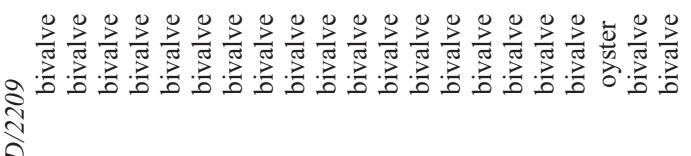

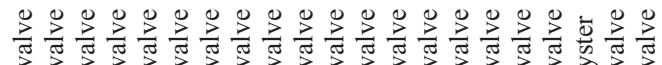

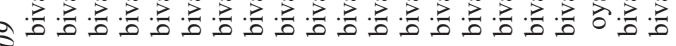
กิ 旅

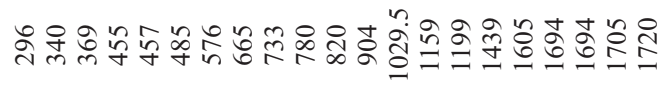

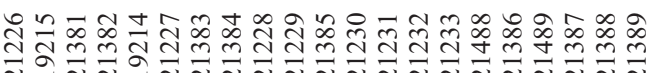

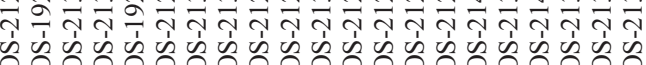

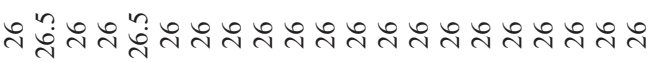

क人

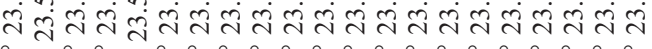

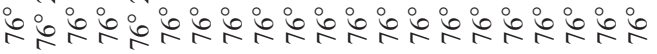

$\infty$ के क्ष जिं

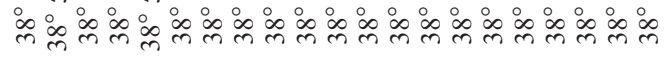

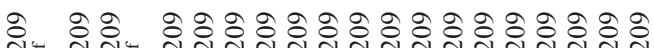
त.

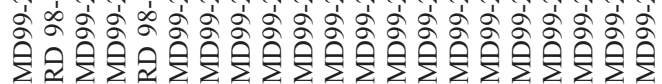

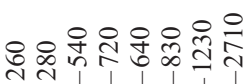

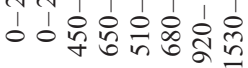

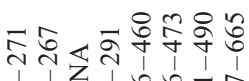

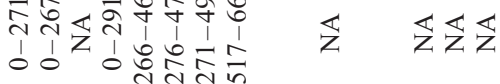

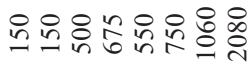

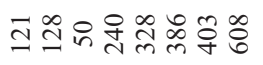

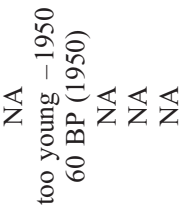

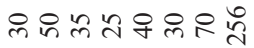

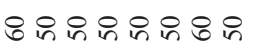

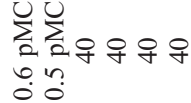

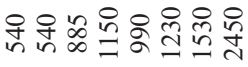

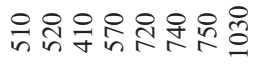

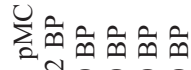

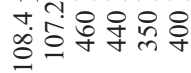

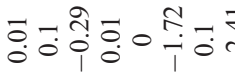

艺艺艺艺艺艺艺艺

i-jón

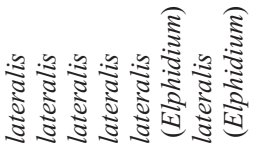

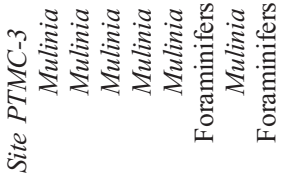

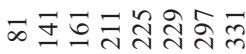

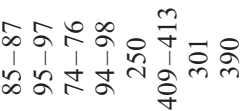

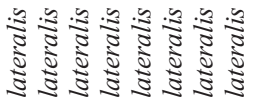

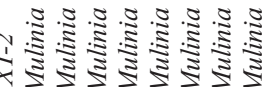

है

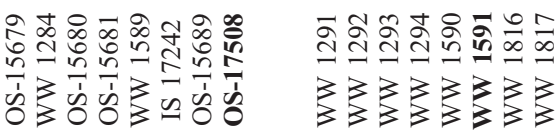

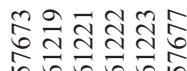

in 6060 는

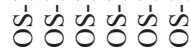

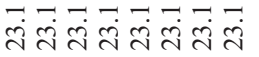

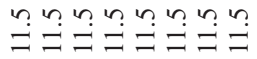

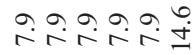

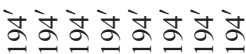

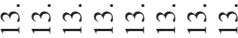

운운운운웅

ำำํำำำำำำำำ

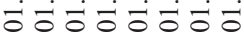

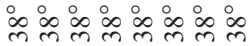

N

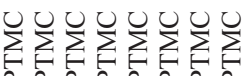

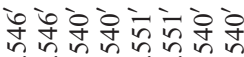

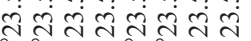

으눈유눈윤ㅇㄴ눈

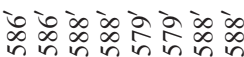
- 2992929

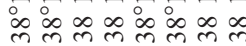

就守字字字学

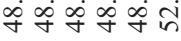

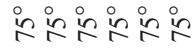

वे

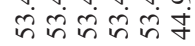

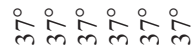

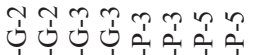

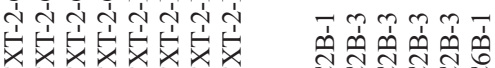

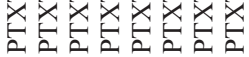




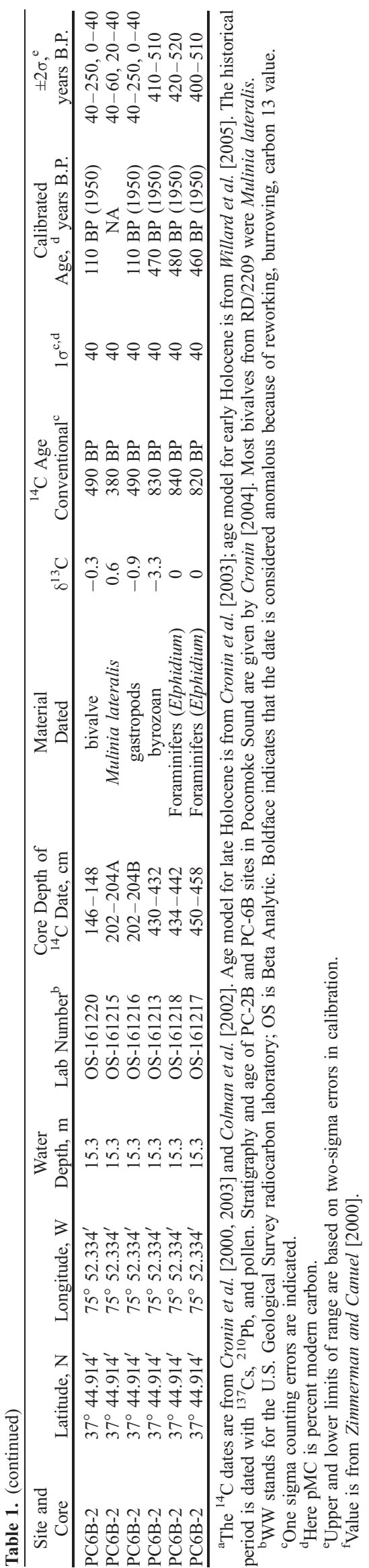

record from Chesapeake Bay. The uppermost $800 \mathrm{~cm}$ at this site were deposited during the last 2200 years and provide a record of multidecadal climate variability during the past two millennia including the Medieval Warm Period ( $\sim$ A.D. $800-1400)$ and the Little Ice Age ( A.D. 1400-1900). Between 800 and $900 \mathrm{~cm}$, there is a condensed zone and/or unconformity representing low sedimentation and possible erosion between $\sim 2200$ and 5900 cal years B.P. The interval from 900 to $1720 \mathrm{~cm}$ is dated at $5900-7200{ }^{14} \mathrm{C}_{\mathrm{cal}}$ years B.P. representing a mean accumulation rate of $\sim 0.6 \mathrm{~cm} \mathrm{yr}^{-1}$ during a time often referred to as the early Holocene thermal maximum. In order to examine decadal variability, we focused on isotopic and $\mathrm{Mg} / \mathrm{Ca}$ variability in the 1400 - to $1620-\mathrm{cm}$ interval, which was deposited over about a 400 -year period.

\subsection{Stable Isotopes}

[12] For stable isotopic analyses, we analyzed between 5-10 specimens of the benthic foraminifera Elphidium selseyense from the $>150$ micron size fraction from samples taken at 2-cm intervals in the cores. E. selseyense is the dominant benthic species in Chesapeake Bay living in the main channel at salinities between about 10 to $25 \mathrm{ppt}$ [Ellison and Nichols, 1976; Karlsen et al., 2000], a range that encompasses estimated Holocene paleosalinity extremes. In general, foraminifers are extremely well preserved in sediments from Pocomoke Sound, most showing no visible signs of postmortem physical or chemical alteration. Isotopic analyses of the foraminifera were made at the University of South Carolina stable isotope laboratory on a VG Optima stable isotope ratio mass spectrometer (IRMS) equipped with an Isocarb single acid bath carbonate preparation system which permits automated runs of 40 samples. All isotope data are presented in notation relative to Vienna Peedee belemnite (VPDB) via our working standard, NBS19. Replicate analyses of this standard yielded an analytical precision of $\pm 0.08 \%$.

[13] To obtain a calibration between oxygen isotope composition and estuarine salinity, water samples were collected along a salinity gradient in the Potomac River and Chesapeake Bay during 1999 and 2000. ${ }^{1}$ Water samples from the Potomac River were taken by hand mainly in mesohaline salinities; samples from the polyhaline region of the bay were taken on board the R/V Holten and Discovery. The oxygen isotope composition of the water was measured at the U.S. Geology Survey (USGS) laboratory in Reston, Virginia. The $\delta^{18} \mathrm{O}$ values were determined by equilibration with $\mathrm{CO}_{2}$ using an automated water equilibrator attached to a Finnigan MAT 251 stable isotope ratio mass spectrometer. The isotope data are reported relative to Vienna standard mean ocean water (VSMOW). Replicate analyses of reference waters yielded an analytical precision of $\pm 0.1 \%$ o $(1 \sigma)$.

\section{3. $\mathrm{Mg} / \mathrm{Ca}$ Ratios}

[14] We used $\mathrm{Mg} / \mathrm{Ca}$ ratios of the estuarine ostracode Loxoconcha to estimate past water temperatures and to correct oxygen isotope values for temperature. For the late

\footnotetext{
${ }^{1}$ Auxiliary material is available at $\mathrm{ftp} / / \mathrm{ftp}$. agu.org/apend/pa/ 2005PA001145.
} 
Estimating Holocene Paleosalinity in Chesapeake Bay

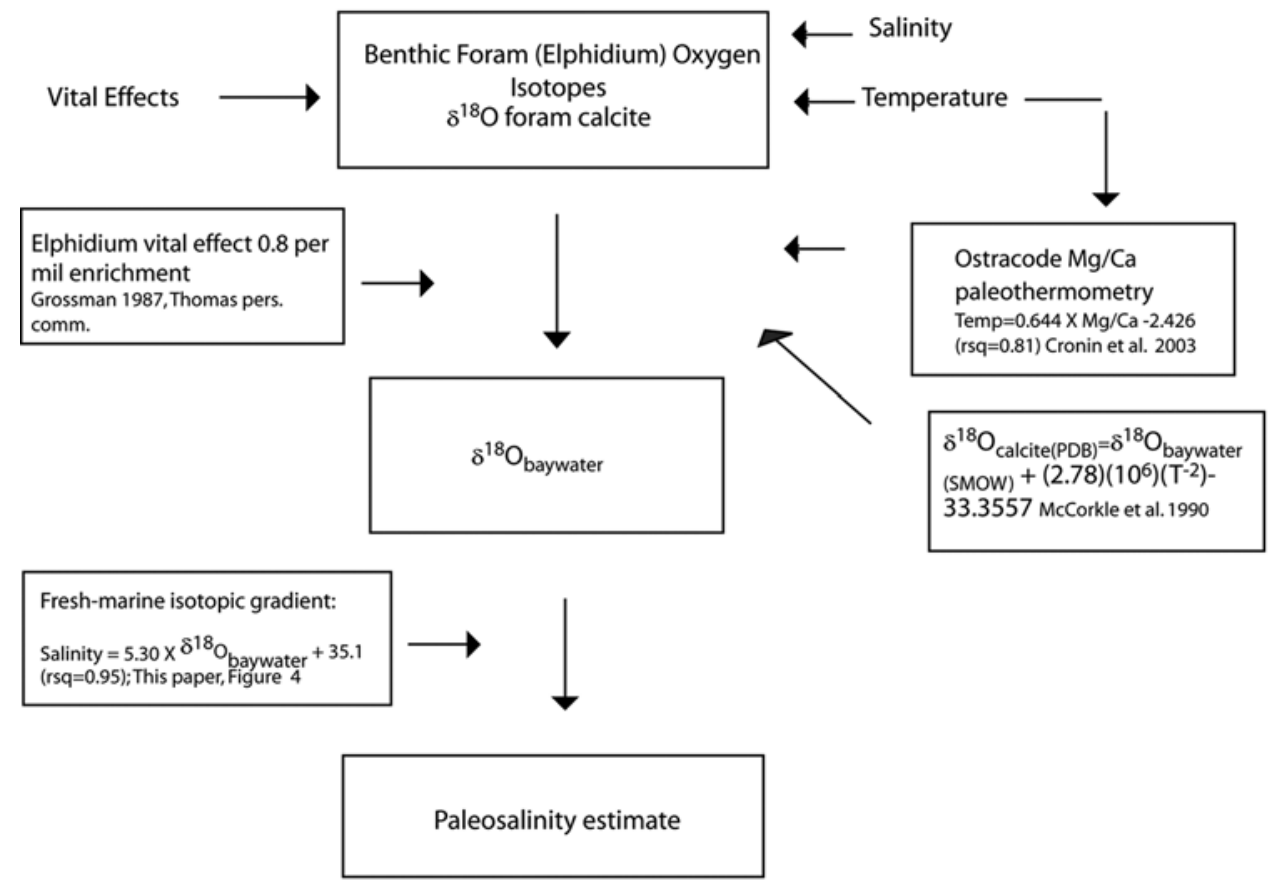

Figure 3. Summary of proxies used to calculate paleosalinity in Chesapeake Bay from oxygen isotopes of Holocene foraminiferal calcite and ostracode $\mathrm{Mg} / \mathrm{Ca}$ temperature estimates.

Holocene, we used the composite paleotemperature record given by Cronin et al. [2003] and supplemented this with new analyses of early Holocene Loxoconcha from RD98/ MD99-2209. Between 1-5 specimens of Loxoconcha sp. were analyzed for $\mathrm{Mg} / \mathrm{Ca}$ ratios at Duke University following the cleaning and analytical procedures discussed in detail by Dwyer et al. [2002] and Cronin et al. [2003] using a Spectrascan Direct Current Plasma Emission spectrometer. Only adult valves and carapaces (two articulated valves) were used. Loxoconcha specimens are too rare in cores PC$6 \mathrm{~B}$ and $\mathrm{PC}-2 \mathrm{~B}$ to obtain temperature records from the southern bay.

[15] All radiocarbon dates, bay $\delta^{18} \mathrm{O}$, foraminiferal stable isotopic and ostracode $\mathrm{Mg} / \mathrm{Ca}$ ratios are available at the USGS website http://geology.er.usgs.gov/eespteam/ Atlantic/or the World Data Center for Paleoclimatology http://www.ngdc.noaa.gov/paleo/paleo.html.

\section{Calibration and Verification}

\subsection{Oxygen Isotopes and Salinity}

[16] We used two approaches to calibrate and verify climate-related proxies for application to Chesapeake Bay Holocene sediments. The more conventional approach to proxy calibration, outlined in Figure 3, involved developing a regression model for modern Chesapeake Bay salinity and $\delta^{18} \mathrm{O}_{\text {water, }}$ and applying it down core to foraminiferal $\delta^{18} \mathrm{O}$ values corrected for water temperature and vital effects to estimate paleosalinity. Figure 4a shows the $\delta^{18} \mathrm{O}_{\text {water-salinity }}$ relationship in the Chesapeake Bay, its tributaries and the adjacent continental shelf. Lower mesohaline waters have $\delta^{18} \mathrm{O}_{\text {water }}$ values around -6 to $-5 \%$, polyhaline waters are near $-3 \%$ and marine waters are -1 to $0 \%$ [Khim and Krantz, 1996]. The freshwater samples in Figure 4a exhibit a wide range of $\delta^{18} \mathrm{O}$ values as would be expected from the influence of short-term temporal and spatial variability in precipitation throughout the watershed region where the

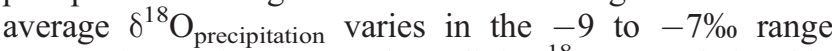
[Rosanski et al., 1993]. The salinity- ${ }^{18} \mathrm{O}_{\text {water }}$ relationship for mesohaline and polyhaline regions $(\sim 5$ to $30 \mathrm{ppt}$, Figure 4) can be expressed by the regression equation:

$$
\text { salinity }=0.1886 \delta^{18} \mathrm{O}_{\text {water }}-6.6188\left(\mathrm{r}^{2}=0.96\right) .
$$

The $\delta^{18} \mathrm{O}_{\text {water }}$ gradient is similar to that found by Ingram et al. [1996] for San Francisco Bay, encompasses the modern and paleosalinity range at our core sites, and excludes values from the highly variable freshwater end-members not pertinent to the current study.

\section{2. $\mathrm{Mg} / \mathrm{Ca}$ Ratios and Paleotemperature}

[17] The oxygen isotopic composition of benthic foraminiferal calcite $\left(\mathrm{CaCO}_{3}\right)$ is influenced by several factors, including water temperature and the isotopic composition of the associated water. The isotopic composition of water in the Chesapeake depends upon the relative proportions of fresh water and ocean water at any given site, and the factors that influence their isotopic compositions. Factors 


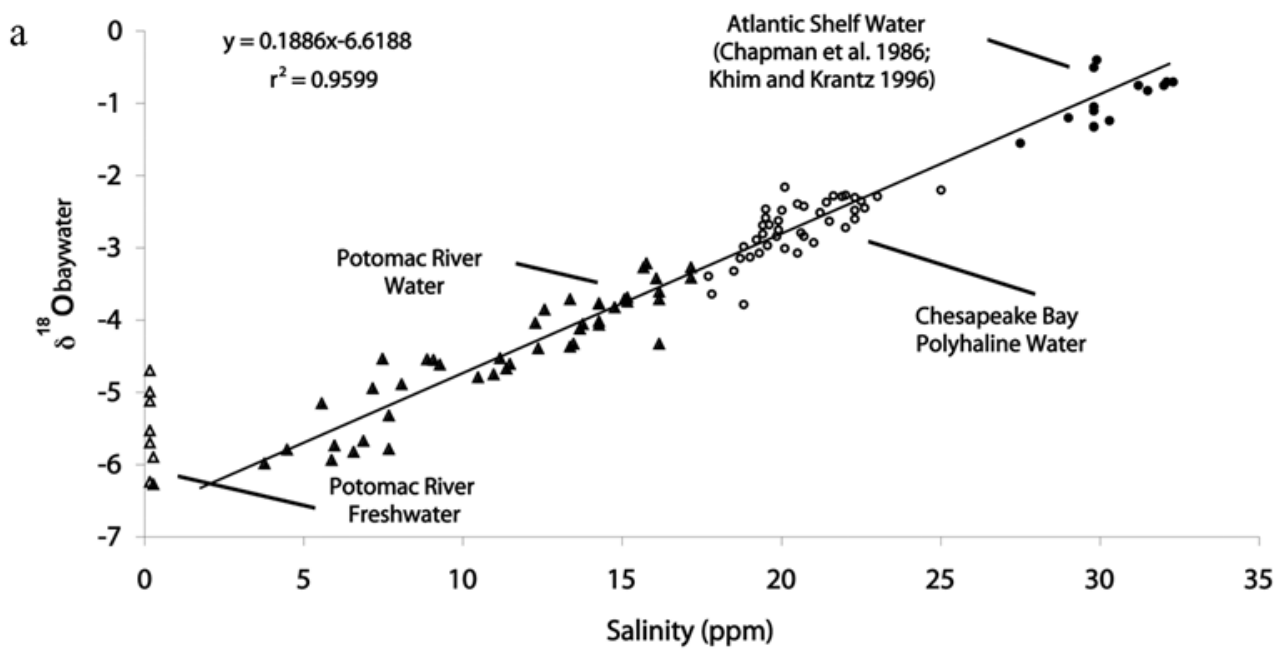

b

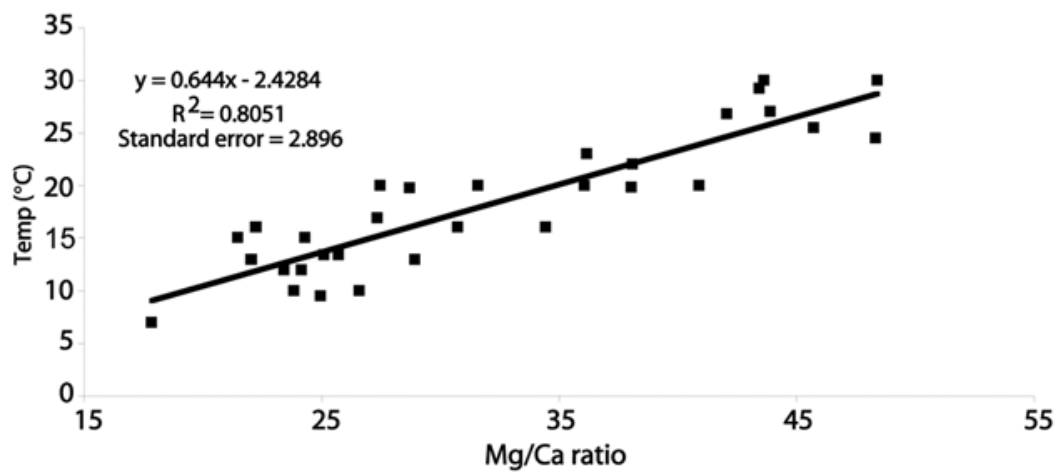

Figure 4. (a) Relationship between oxygen isotopic rations and salinity in Chesapeake Bay, Potomac River estuary, and Atlantic shelf water. (b) Relationship between $\mathrm{Mg} / \mathrm{Ca}$ ratios in adult ostracode Loxoconcha shells and water temperature [see Cronin et al., 2003].

affecting freshwater compositions were discussed above. An important factor contributing to the isotopic composition of ocean through geologic time is the global ice volume. Thomas et al. [2000] showed that the $\delta^{18} \mathrm{O}_{\text {foram values of }}$ Elphidium collected from Long Island Sound increase with increasing salinity. In order to correct Chesapeake Holocene $\delta^{18} \mathrm{O}_{\text {form }}$ for past temperature changes, we used ostracode $\mathrm{Mg} / \mathrm{Ca}$ ratios to estimate paleotemperature in paired ostracode-foraminiferal samples from $\mathrm{RD} / 2209 . \mathrm{Mg} / \mathrm{Ca}$ ratios in ostracodes are influenced by the temperature and the $\mathrm{Mg} / \mathrm{Ca}$ ratio $\left(\mathrm{Mg} / \mathrm{Ca}_{\text {water }}\right)$ of the water in which the shell is secreted [e.g., Dwyer et al., 2002, and references therein]. Because of the well-mixed nature of magnesium and calcium in seawater and their significantly higher concentration relative to freshwater inflow to the bay, we assume that $\mathrm{Mg} / \mathrm{Ca}_{\text {water }}$ remains constant (at the seawater value) and therefore has negligible influence on ostracode $\mathrm{Mg} / \mathrm{Ca}$ ratios at the timescales and salinities relevant to this study. We used the $\mathrm{Mg} /$ Ca-temperature regression model for the estuarine ostracode Loxoconcha developed for Chesapeake Bay by Cronin et al.
[2003] based on modern specimens collected from a range of water temperatures $\sim 10^{\circ}-26^{\circ} \mathrm{C}$ (Figure $4 \mathrm{~b}$ ). This relationship is expressed as

$$
\mathrm{T}=0.644\left(\mathrm{Mg} / \mathrm{Ca}_{\text {shell }}\right)-2.4284\left(\mathrm{r}^{2}=0.81\right) .
$$

Using paleotemperatures ( $\mathrm{T}$ ) estimated from this relationship, we converted $\delta^{18} \mathrm{O}_{\text {foram }}$ to $\delta^{18} \mathrm{O}_{\text {baywater }}$ using the relationship from McCorkle et al. [1990]:

$$
\begin{aligned}
\delta^{18} \mathrm{O}_{\text {foram }}= & \delta^{18} \mathrm{O}_{\text {water }}(\mathrm{SMOW})+\left(2.78 * 10^{6}\right)\left(\mathrm{T}^{-2}\right) \\
& -33.3557
\end{aligned}
$$

\subsection{Seasonal Ecology and Shell Secretion}

[18] It is also important to consider the seasonal ecology and time of shell secretion in both Loxoconcha and Elphidium for interpreting paired $\delta^{18} \mathrm{O}_{\text {foram }}$ and $\mathrm{Mg} / \mathrm{Ca}$ values. 
Ostracodes grow in 8 or 9 discrete molt stages and studies of the seasonal ecology of Loxoconcha matagordensis [Vann et al., 2004; Cronin et al., 2005] indicate that most adults secrete their shells during spring and summer seasons and thus the paleotemperature record is mainly a warm season record. Other temperate species of Loxoconcha have similar seasonal ecology and grow adult shells during spring and/or summer. Available ecological data on Elphidium from Chesapeake Bay suggests that most shell growth also occurs during spring and summer [Buzas, 1969; M. Buzas, personal communication 2003]. Thus, to a first approximation, the isotopic and $\mathrm{Mg} / \mathrm{Ca}$ ratios of paired down core Elphidium and Loxoconcha represent similar warm season conditions.

\subsection{Vital Effects}

[19] Another factor to consider when using oxygen isotopes of foraminifera for paleosalinity reconstructions is that different taxa secrete their shells in isotopic disequilibrium with the ambient water. Grossman [1987] surveyed a large number of foraminiferal genera and suggested such a "vital effect" offset for Elphidium of $0.8 \%$. An offset of about $1.1 \%$ has also been observed for Long Island Sound Elphidium by E. Thomas (personal communication, 2003). Applying corrections of $0.8 \%$ and $1.1 \%$ to estimated $\delta^{18} \mathrm{O}_{\text {baywater }}$ derived from Holocene Chesapeake Elphidium, we found that the higher value of $1.1 \%$ results in mean salinity estimates $\sim 7.5 \%$ lower than those from the $0.8 \%$ o correction (mean salinity $=20.7$ versus $22.3 \mathrm{ppt}$ ). This source of error affects the absolute paleosalinity estimates but does not appreciably change the interpretation of largescale isotopic excursions during the Holocene. Paleosalinity reconstructions given below use the $0.8 \%$ vital effect offset pending further study of Elphidium ecology, ontogeny, and shell chemistry.

\subsection{Verification}

[20] We used the instrumental record of Susquehanna River discharge for the period $1900-1990$ as a means to verify down core $\delta^{18} \mathrm{O}_{\text {foram }}$ patterns as estimates of paleosalinity (Figure 5a). Najjar [1999] has shown that discharge is positively correlated with regional precipitation for the period 1900-1987 and Austin [2004] showed that Chesapeake Bay salinity responds synchronously to streamflow. The $\delta^{18} \mathrm{O}_{\text {foram }}$ record shows that, with some exceptions, major decadal changes in discharge are manifested in isotopic excursions at all four core sites along a north-south a transect along the bay axis. The contrast between low discharge/high $\delta^{18} \mathrm{O}_{\text {water }}$ values during the dry $1960 \mathrm{~s}$ and high discharge/low ${ }^{18} \mathrm{O}_{\text {water }}$ during the wet 1970 s is the most evident climatic event during the period of record. In fact, this shift coincides with the unprecedented shift toward positive NAO conditions beginning in the late 1960s [Hurrell et al., 2003]. Our results suggest that the oxygen isotopic record captures discharge-driven mixing of marine and freshwater in the mesohaline and polyhaline region of the bay and that decadal salinity variability is most likely baywide and synchronous within the limits of the core age models. They also show that $\delta^{18} \mathrm{O}$ records from estuaries can provide an isotope stratigraphy that can be used to correlate sediments within the bay and, at least potentially, among different coastal bays and estuaries influenced by the same regional precipitation.

[21] As a means to crosscheck the $\mathrm{Mg} / \mathrm{Ca}$ paleothermometry model, the down core $\mathrm{Mg} / \mathrm{Ca}$ temperature anomalies from the upper $200 \mathrm{~cm}$ of $\mathrm{RD} / 2209$ were compared with spring oceanic temperatures from the Comprehensive Ocean-Atmosphere Data Set (COADS) from the region off the mouth of Chesapeake Bay $\left(75.7-76.5^{\circ} \mathrm{W} ; 36.5-\right.$ $37.5^{\circ} \mathrm{N}$, Figure $5 \mathrm{~b}$ ). Interannual temperature variability recorded in COADs and Chesapeake Bay monitoring records over the past 20 years show strong visual correspondence to one another [Cronin et al., 2003]. Allowing for age uncertainty in the sediment record of $\sim \pm 5$ years due to mixing, there is a good match between the COADs and reconstructed temperatures, especially for the relatively warm 1940-1950s and the cold 1960s to the warmer 1970s. Similar results were observed using COADs winter temperatures. The apparent minor offset between the sediment core and COADs temperature trends is most likely due to sediment mixing and dating uncertainty rather than Chesapeake temperatures lagging those of the broader north Atlantic atmosphere-ocean system, because instrumental records of Chesapeake temperatures show bay temperature trends are similar to oceanic COADS temperatures at monthly timescales over the past 20 years [Cronin et al., 2003]. Significantly, these regional oceanic temperature trends appear to reflect broad twentieth century oceanic SST patterns occurring at decadal timescales in the western North Atlantic Ocean [Deser and Blackmon, 1993].

\subsection{Carbon Isotopes}

[22] Carbon isotopic ratios in estuarine water and sediments are controlled by the source of the organic carbon, which is influenced largely from the mixing of lighter $(\sim-26 \%)$ terrestrially derived organic matter and heavier ( 20\%) marine organic matter. These carbon sources influence the composition of the dissolved inorganic carbon (DIC) taken up by foraminifera during shell growth. In addition, within Chesapeake Bay a covariance exists between the $\delta^{13} \mathrm{C}$ of water and salinity. Specifically, there is a gradient from more negative $\delta^{13} C_{w a t e r}$ values in lower salinity in the north to more positive values in the south, which reflects the influence of high terrestrial carbon influx from the freshwater sources [Spiker, 1978; Bratton et al., 2003b]. In this sense, the $\delta^{13} \mathrm{C}$ of benthic foraminifera can be used as an indirect proxy for salinity

[23] However, as shown by Spiker [1978] for Chesapeake Bay and Thomas et al. [2000] for Long Island Sound, other geochemical processes operating within the estuary can also influence the carbon isotopic composition of the DIC available to foraminifera for shell secretion. The two most important processes are primary productivity, which leads to higher isotopic values when productivity is high, and oxidation of organic matter in the water column or near the bay bottom, which leads to lower values [Anderson and Arthur, 1983; Thomas et al., 2000]. These processes, especially oxidation in the deep channel of Chesapeake Bay where seasonal hypoxia has occurred for at least a century [Zimmerman and Canuel, 2000; Cronin and Vann, 


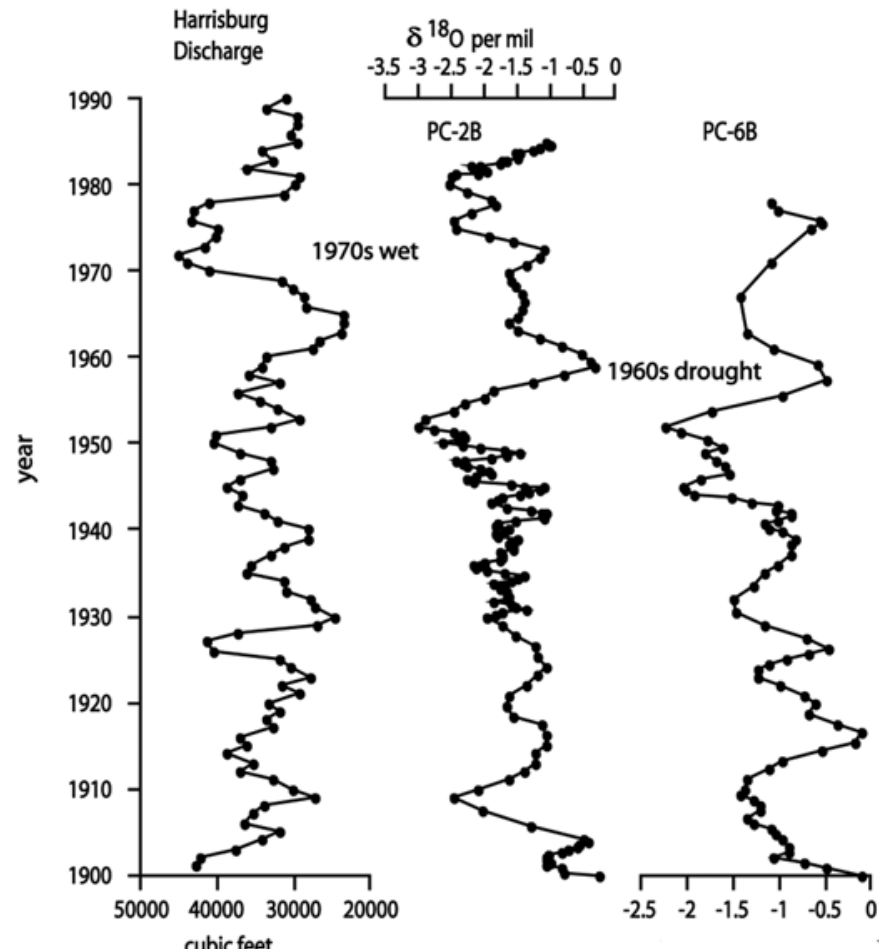

$\delta^{18}$ O per mil
-3

A
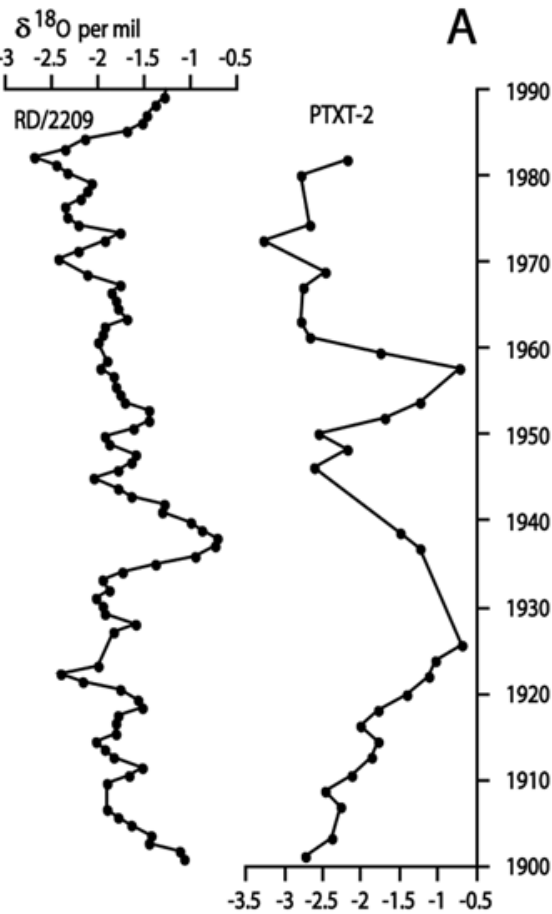

cubic feet
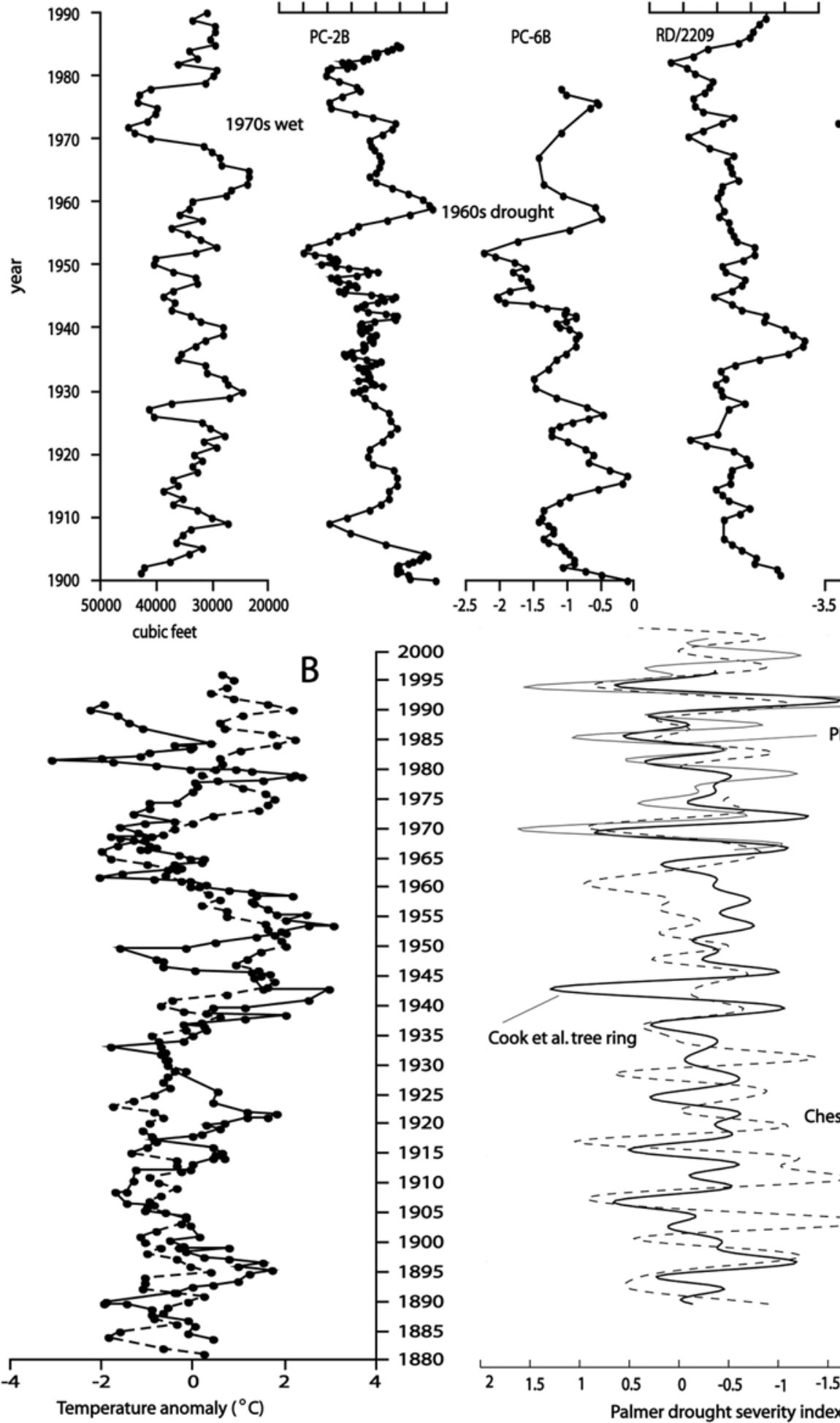

$\begin{array}{lllllllllllll}-3.5 & -3 & -2.5 & -2 & -1.5 & -1 & -0.5\end{array}$
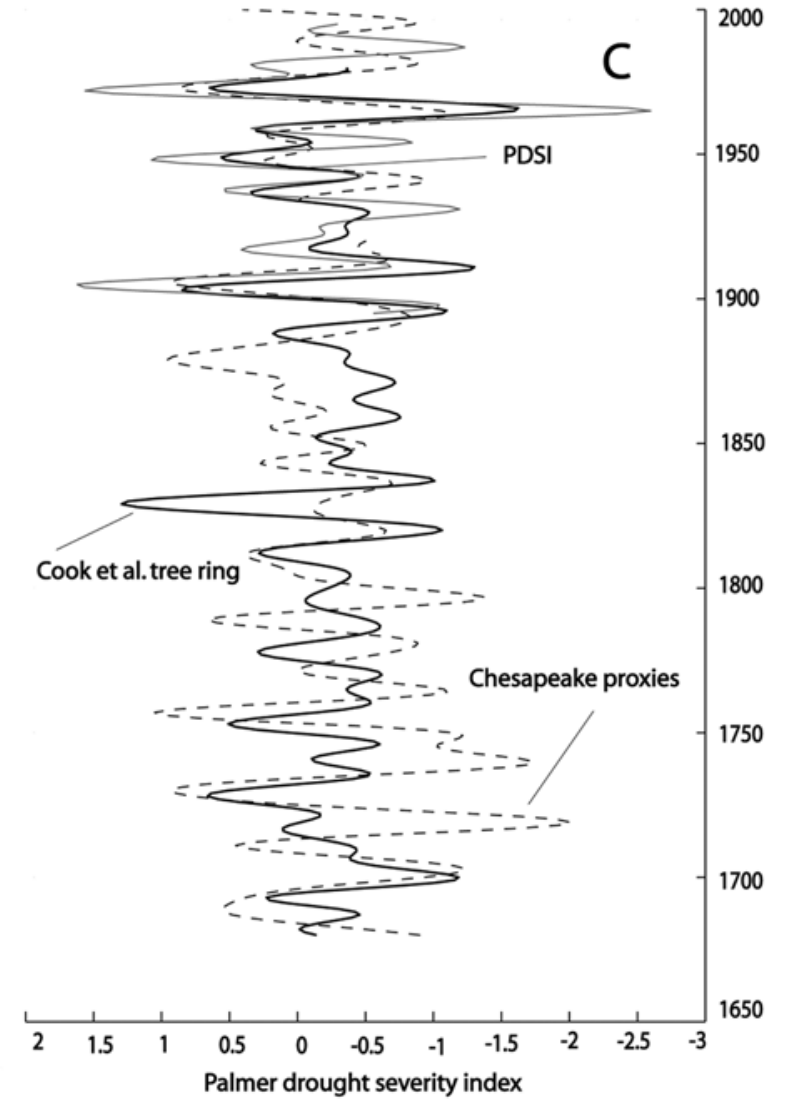

Figure 5 
Table 2. Calibration/Cross-Validation Statistics for Chesapeake Bay Holocene Multiproxy Data

\begin{tabular}{lccc}
\hline & Interval & $\mathrm{Mg} / \mathrm{Ca}-{ }^{18} \mathrm{O}-{ }^{13} \mathrm{C}$ & Tree Ring \\
\hline Calibration & $1928-1995$ & 0.31 & 0.71 \\
Cross validation & $1895-1927$ & 0.51 & 0.35 \\
\hline
\end{tabular}

${ }^{\mathrm{a}}$ Values are from Cook et al. [2002].

2003], might account for temporal patterns in $\delta^{13} C_{\text {foram }}$ that do not seem to vary in association with salinity.

[24] Carbon derived from different types of terrestrial plants can also be a source of variability; $\mathrm{C}_{3}$ plants (trees shrubs) usually have lower $\delta^{13} \mathrm{C}$ than $\mathrm{C}_{4}$ plants (e.g., grasses). Similarly, marsh plants and submerged aquatic grasses living along the margins of Chesapeake Bay have relatively high carbon isotopic values. However, Bratton et al. [2003b] concluded from a study of carbon isotopes in Chesapeake Bay sediments that neither terrestrial plant type nor coastal marsh and sea grass sources had an appreciable influence on $\delta^{13} \mathrm{C}$ trends obtained from fine-grained sediments deposited in deeper regions of Chesapeake Bay where our cores were taken and Elphidium lives. Elphidium is also known to have photosynthetic endosymbionts living in its shell, but it is not clear if these influence the Chesapeake foraminiferal carbon isotope composition.

[25] Two other factors can influence the $\delta^{13} \mathrm{C}$ values on benthic foraminifers: vital effects and microhabitat effects. Vital effects in $\delta^{13} \mathrm{C}_{\text {foram }}$ are caused by either metabolic processes (i.e., algal or bacterial symbionts living in the foraminifera [Romanek et al., 1992]) or kinetic processes, related to how fast the organism secretes its shell. Microhabitat effects involve differences in the isotopic composition of DIC in bottom water versus sediment pore water. Chandler et al. [1996] found a strong microhabitat effect in experimentally cultured Ammonia from the Gulf of Mexico

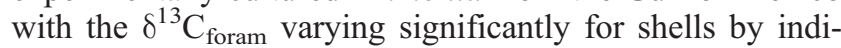
viduals living epifaunally (in bottom water) versus those living infaunally (in pore water).

[26] Owing to these complex, partially understood processes, we did not develop a quantitative relationship between $\delta^{13} \mathrm{C}_{\text {foram }}$ and specific environmental parameters. Although in situ productivity and terrestrial carbon influx are certainly important over seasonal [Canuel, 2001] and centennial times because of postcolonial land clearance [Bratton et al., 2003b], the similarity of decadal patterns for foraminiferal carbon and oxygen isotopes presented below indicate that for certain periods during the Holocene, $\delta^{13} \mathrm{C}_{\text {foram }}$ patterns are correlated at least in part with salinity.

\subsection{Multivariate Calibration}

[27] In addition to the $\delta^{18} \mathrm{O}$-salinity and $\mathrm{Mg} / \mathrm{Ca}$-temperature calibrations, we also used a multivariate approach to calibrate the three geochemical proxies to climate indices because multiple factors such as ecology, taphonomy, and vital effects can introduce varying degrees of uncertainty into any single proxy record. We first interpolated the isotope and $\mathrm{Mg} / \mathrm{Ca}$ data onto an annual timescale, and then smoothed decadally. We applied a high-pass filter to the $\delta^{13} \mathrm{C}$ data to remove variations on timescales longer than 40 years, because low-frequency changes in $\delta^{13} \mathrm{C}$ may reflect changes in sedimentation, human agricultural influences, and other nonclimatic influences of the carbon budget.

[28] We then performed a multivariate calibration of the three smoothed predictors against various target instrumental records (also smoothed decadally). These included (1) summer (JJA) Palmer Drought Severity Index (PDSI), a robust indicator of precipitation, for the nearest grid box (centered $39^{\circ} \mathrm{N}, 77.5^{\circ} \mathrm{W}$ ) and (2) warm season (April-September) and (3) cold season (October-March) temperature for the nearest grid box $\left(37.5^{\circ} \mathrm{N}, 77.5^{\circ} \mathrm{W}\right)$. PSDI and temperature data come from Cook et al. [1999] (see http://www.ncdc.noaa.gov/ paleo/pdsi.html) and Jones et al. [1999] (see http:// www.cru.uea.ac.uk/cru/data/temperature/), respectively.

[29] Atmospheric temperature data were available from 1854 to 1993 and PDSI drought data from 1895 to 1995 , and we attempted various calibration/cross-verification experiments, performing the multivariate regression over one subperiod, and testing the skill of the resulting reconstruction using the independent period. There was no skillful reconstruction found for temperature, perhaps because the temperature signal in the $\mathrm{Mg} / \mathrm{Ca}$ is seasonal in nature, and maybe not well captured by either the cold season or warm season half year. Conversely, there is a remarkably skillful drought reconstruction and we settled on a 1928-1995 calibration period, and a verification period of 1895-1927. The latter is the same cross-verification interval used by Cook et al. [1999] in his (1895-1980) tree ring based reconstructions of summer PDSI for the same grid box. The calibration cross-verification statistics are summarized in Table 2.

[30] The regression model gives partial normalized regression coefficients as follows: $\mathrm{Mg} / \mathrm{Ca}: 0.31, \delta^{13} \mathrm{C}: 0.67$ and $\delta^{18} \mathrm{O}:-0.03$. The first two are significant at the 2 sigma

Figure 5. (a) Verification of relationship between foraminiferal oxygen isotope ratios for cores PC-2B, PC-6B, RD/2209, and PTXT-2 and Susquehanna River discharge measured at Harrisburg, Pennsylvania, for the last century. $X$ axis for discharge panel is reversed; intervals of low discharge correspond to relatively positive isotopic values. All curves are threepoint moving average. (b) Comparison of smoothed water temperature anomalies from Comprehensive Ocean-Atmosphere Data Set (COADS) oceanic temperatures from region off the mouth of Chesapeake Bay (dashed line) and paleotemperatures estimated from ostracode $\mathrm{Mg} / \mathrm{Ca}$ ratios (solid line). (c) Comparison of Palmer Drought Severity Index (PDSI) (light shaded solid line) with tree ring drought reconstruction for the eastern United States (solid dark line) from Cook et al. [1999] and Chesapeake Bay multivariate climate reconstruction (dashed line). Tree ring and Chesapeake reconstructions are compared during the period of overlap back to A.D. 1680. Note many of the individual decadal peaks are in common in the two reconstructions; the primary difference is that the Chesapeake reconstruction shows more lowfrequency variability, perhaps because the tree ring data were conservatively detrended and do not retain low-frequency variability. Two prominent droughts near 1790s and 1870s may signify large El Niño events. 


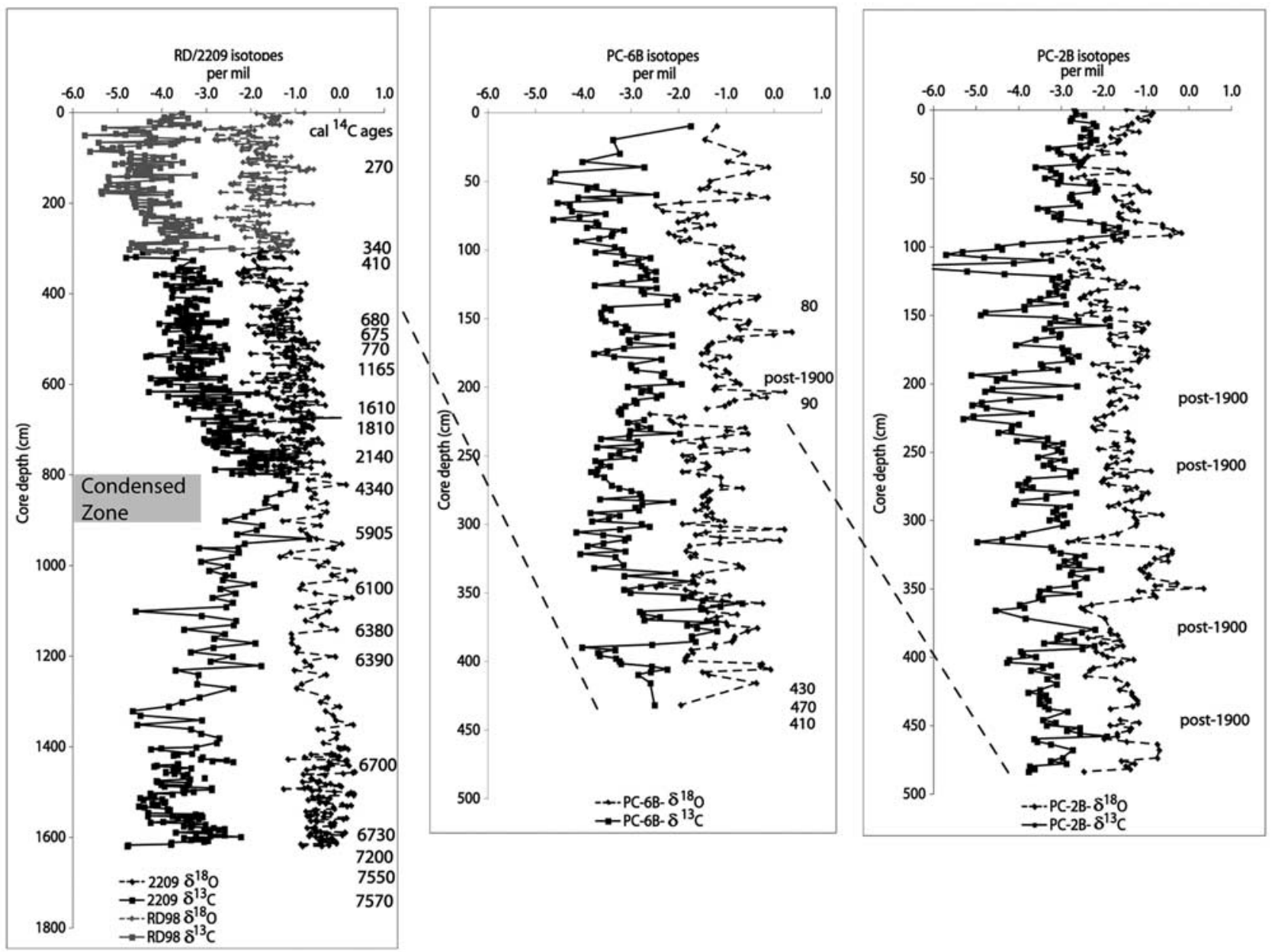

Figure 6. Foraminiferal oxygen (dashed lines) and carbon isotopic (solid lines) values from (left) RD/ 2209 from the north central Chesapeake Bay, (middle) PC-6B, and (right) PC-2B from Pocomoke Sound in the southern part of the bay. PC-2B is from shallower water depth (7.9 m versus $15.3 \mathrm{~m}$ for PC-6B) and located more proximal to the Pocomoke River mouth. Radiocarbon control points from Table 1 are indicated at the right of each plot. Dashed diagonal lines show approximate lines of correlation among cores.

level. It is somewhat surprising that no significant relationship with $\delta^{18} \mathrm{O}_{\text {foram }}$ is found given the salinity- $\delta{ }^{18} \mathrm{O}_{\text {water }}$ discussed above. Again, as discussed above, this may have to do with differences between seasonality of the target PDSI signal and the seasonal window reflected by the $\delta^{18} \mathrm{O}$ measurements.

[31] These calibration and verification results are presented in Figure 5c, along with a comparison of the Chesapeake reconstruction with Cook's PDSI back to 1680. Results suggest that, despite uncertainty in the individual proxy calibrations due to multiple factors influencing isotope and $\mathrm{Mg} / \mathrm{Ca}$ values and possible nonsynchroneity of foraminiferal and ostracode shell secretion, the multivariate reconstruction provides a robust climate signal that can be verified using independent climate and paleoclimate data. The isotope-based reconstruction seems to indicate greater decadal variability in drought over the past few centuries than would be inferred from the Cook et al. [1999] tree ring-based reconstructions. One interpretation of this find- ing is that the conservative standardization of tree ring chronologies underestimates the amplitude of decadal and multidecadal drought changes. In any case, these findings underscore the usefulness of employing various alternative proxy estimates of past changes in climate variables such as continental drought.

\section{Results}

\subsection{Stable Isotope Curves}

[32] Figure 6 shows the $\delta^{18} \mathrm{O}_{\text {foram }}$ and $\delta^{13} \mathrm{C}_{\text {foram }}$ values from RD/2209 and PC-6B and PC-2B from Pocomoke Sound plotted against core depth indicating radiocarbon age-control points. The results show that early Holocene $\left(900-1650 \mathrm{~cm}\right.$ core depth) $\delta^{18} \mathrm{O}$ values vary in a narrow range from -1 to $0 \%$ and $\delta^{13} \mathrm{C}$ values become progressively more positive (from $-3.5 \pm 0.5 \%$ to $-1.5 \pm$ $0.5 \%$ ) in the same interval. Late Holocene $\delta^{18} \mathrm{O}$ and $\delta^{13} \mathrm{C}$ values at this site both show a progressive trend 
toward more negative values up core, with the carbon isotope trend being more notable. Short-term excursions in both carbon and oxygen isotopes are superimposed on long-term trends (see below). Pocomoke Sound records PC-6B and PC-2B of the past 500 and $\sim 150$ years, respectively, show that, with some exceptions especially at $\mathrm{PC}-6 \mathrm{~B}$, carbon and oxygen excursions occur in phase with one another over decadal and multidecadal timescales. These results confirm our hypothesis that both isotopes are being influenced largely by river discharge and salinity-related processes.

[33] Comparison of mean $\delta^{18} \mathrm{O}_{\text {foram }}$ and $\delta^{13} \mathrm{C}_{\text {foram values }}$ for cores $\mathrm{RD} / 2209$, PC- $6 \mathrm{~B}$, and $\mathrm{PC}-2 \mathrm{~B}$ also illustrates the likelihood that salinity is the dominant control over the isotope record because the latitudinal and vertical salinity gradients that result from the bay's circulation should be reflected in the isotope record. Other factors being equal, one would expect more negative values in more proximal (less saline, closer to freshwater inflow), and in shallower locations (less dense low salinity water) and more positive values in distal and deeper water sites (Figure 2). Mean $\delta^{18} \mathrm{O}_{\text {foram }}$ values for sediments deposited during the last $\sim 500$ years in RD/2209 and PC-6B, and for the $\sim 100$ 200 years for PC-2B are $-1.73 \%,-1.20 \%$, and $-1.61 \%$, respectively. Comparable $\delta^{13} \mathrm{C}_{\text {foram values are }-4.07 \% \text {, }}$ $-3.0 \%$, and $-3.3 \%$. As expected, mean values for $\mathrm{RD} /$ 2209 from the northern bay are more negative than those for PC-2B and PC-6B, located in the southern bay, closer to the source of marine waters. Similarly, within Pocomoke Sound, PC-2B, taken at $7.9 \mathrm{~m}$ water depth closer the mouth of the Pocomoke River, has more negative values than those at PC-6B, located more distally at 15.3 meters depth. These relationships also hold true if one compares mean values for those intervals representing the past 2 centuries (the entire $484 \mathrm{~cm}$ at $\mathrm{PC}-2 \mathrm{~B}$ and the uppermost $300 \mathrm{~cm}$ at $\mathrm{PC}-6 \mathrm{~B})$.

\subsection{Patterns of Holocene Salinity and Temperature}

[34] The paleosalinity and paleotemperature reconstructions using the calibrations derived above are plotted against age in Figure 7. The salinity record comes from core $\mathrm{RD} /$ 2209; the temperature record combines the late Holocene record from Cronin et al. [2003], with the early Holocene record from core $\mathrm{RD} / 2209$. The data indicate that mean early Holocene paleosalinity was $28 \mathrm{ppt}$ at this site, falling to $20 \mathrm{ppt}$ during the late Holocene, a greater than $25 \%$ decrease during the Holocene. For comparison, modern mean annual salinity at depths of 21-26 m during 19842001 at Chesapeake Bay monitoring station CB3.3 near the $\mathrm{RD} / 2209$ core site is $\sim 17 \mathrm{ppt}$ indicating modern salinity is nearly $40 \%$ lower than during the early Holocene. In addition to multidecadal salinity oscillations, rapid stepwise drops in mean salinity are seen at $\sim 6500-6400$ years B.P. and at $\sim 1100-800$ years B.P.

[35] Early Holocene $\mathrm{Mg} / \mathrm{Ca}$ temperatures varied in a relatively narrow range of $13^{\circ}$ to $16^{\circ} \mathrm{C}(\mathrm{Mg} / \mathrm{Ca}$ ratios $=$ $20->30 \mathrm{mmol} / \mathrm{mol}$ ) with a mean temperature of $14.2^{\circ} \mathrm{C}$, with a few excursions over $20^{\circ} \mathrm{C}$. Temperatures during the late Holocene were, on average, lower (mean temperature $=$ $\left.12.8^{\circ} \mathrm{C}\right)$, but temperatures exceeding $14.6^{\circ} \mathrm{C}(\mathrm{Mg} / \mathrm{Ca}=$ $30 \mathrm{mmol} / \mathrm{mol}$ ) are common during the Medieval Warm Period (we refer to the MWP as the interval $\sim 1200-600$ years B.P. [see Cronin et al., 2003]) and the last century.

\subsection{Early Holocene Decadal Variability}

[36] Owing to high accumulation rates, core RD/2209 offers an opportunity to examine decadal-scale climate variability during the early Holocene thermal maximum. Figure 8 shows three-point moving averages of $\delta^{18} \mathrm{O}_{\text {foram }}$ revealing evidence for eleven positive oxygen isotope excursions between 1400 and $1620 \mathrm{~cm}$, an interval representing approximately 400 years about 7000 years B.P. Most of these isotopic events correspond to positive (warmer) $\mathrm{Mg} / \mathrm{Ca}$ excursions, although the magnitude and timing of peak isotopic and $\mathrm{Mg} / \mathrm{Ca}$ values do not always coincide with one another. Nonetheless, these results suggest that during the early Holocene, relatively warm conditions often coincided with wet periods over decadal (30-40 years) timescales.

\subsection{Spectral Analyses}

[37] Spectral analyses were performed on the carbon, oxygen, and $\mathrm{Mg} / \mathrm{Ca}$ data from the early and late Holocene intervals (Figure 9). The series were first low-passed at $f=$ 0.1 cycle/year and decimated to yield uniform decadal time spacing. Spectra were computed using the multiple taper approach, employing the method of Mann and Lees [1996] to estimate statistical significance of peaks (median, 90\%, $95 \%$, and $99 \%$ ) relative to a red noise null hypothesis. Spectra are shown for frequencies $<0.05$ cycle year $(>20$-year period) owing to the decadal low pass; the multitaper spectrum (and median, 90\%, 95\%, and 99\% confidence levels based on red noise assumption) for each series (frequency is in cycles $/ 5$ years). The bandwidth used for the latter is twice that for the former, owing to the roughly double length of the available series. The spectral analyses indicate that for all three proxies there is a tendency for significant multidecadal variability in the 40 - to 80 -year timescale during the early Holocene and a shift toward shorter, roughly bidecadal (20-30 years) variability during the late Holocene. Interestingly, a tendency for enhanced variability in the North Atlantic region is found at both of these timescales in proxy data spanning the past few centuries [Mann et al., 1995], favoring the interpretation that the spectral features detected in the Chesapeake Bay isotope series may indeed reflect a regional expression of largerscale climate processes related to the NAO and coupled ocean-atmosphere processes in the North Atlantic.

[38] Spectral coherences between each pair of proxies (based on multitaper spectral analysis) show some consistent (i.e., similar for both early and late intervals) evidence for coherent peaks at decadal through multidecadal timescales, and little coherence at secular timescales [see Mann and Park, 1993]. We thus resist the temptation to interpret the lowest-frequency (multicentury) attributes of the time series.

\section{Comparison to Low- and High-Latitude Records}

[39] It is instructive to compare the Holocene midlatitude climatic record from Chesapeake Bay with those 


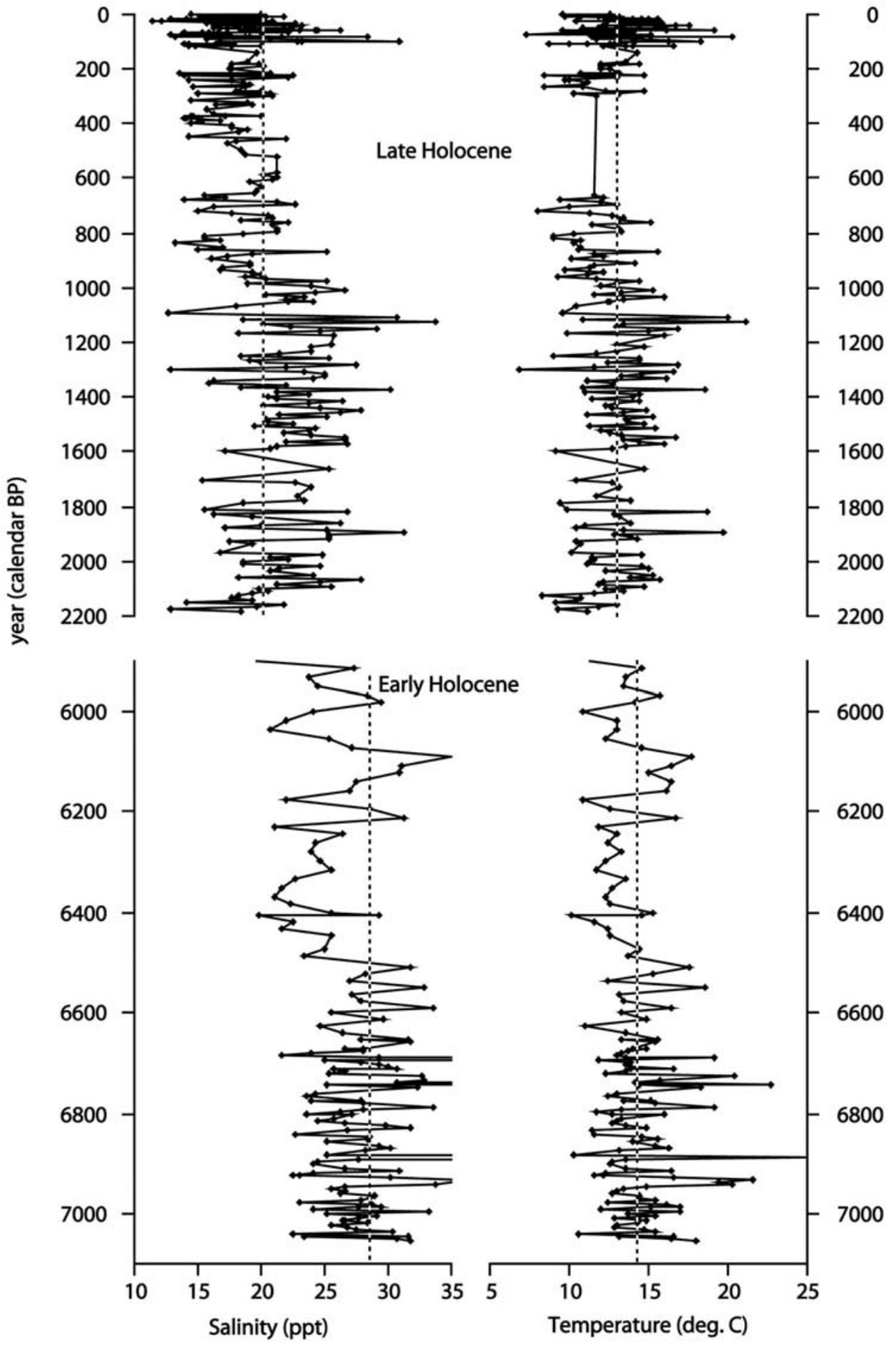

Figure 7. Comparison of paleosalinity from foraminiferal oxygen and carbon isotopes and $\mathrm{Mg} / \mathrm{Ca}-$ based paleotemperature based on ostracode $\mathrm{Mg} / \mathrm{Ca}$ relationships in Figures 3 and 4. Late Holocene record is a composite temperature record from three cores given by Cronin et al. [2003]. Age model is based on radiocarbon dates given in Table 1 , discussed in text.

from low and high latitudes of the North Atlantic region. One important decadal-scale paleoclimate record is titanium flux in sediments from the Cariaco Basin, which is interpreted by Haug et al. [2001] to signify variability in
Orinoco River discharge due to short- and long-term migrations of the Intertropical Convergence Zone (ITCZ) during the late glacial and Holocene. A comparison of the broad-scale features of the Cariaco Basin and Chesapeake 


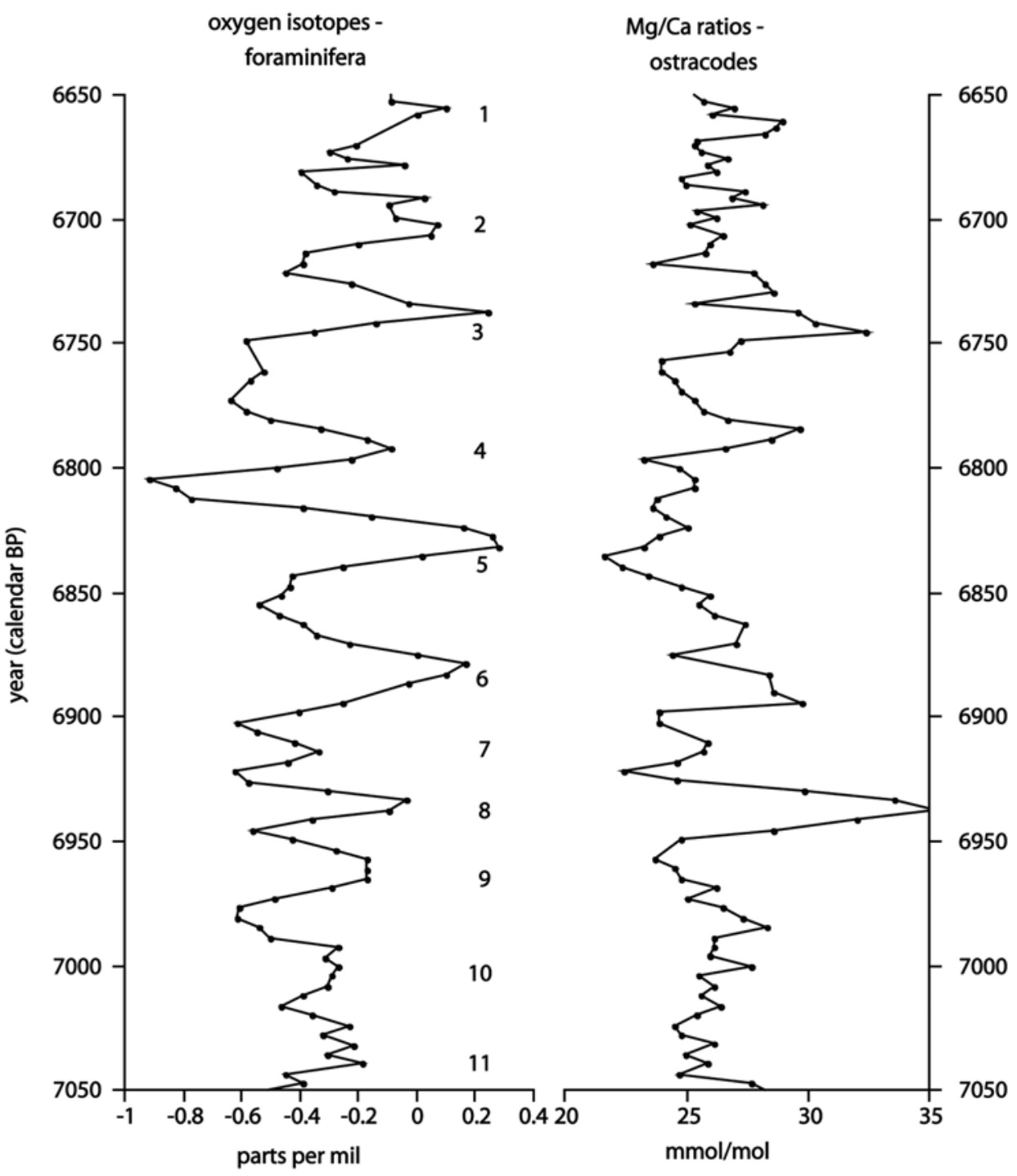

Figure 8. Details of isotopic and $\mathrm{Mg} / \mathrm{Ca}$ record for the early Holocene multidecadal events between 7050 and 6650 years B.P. Eleven informal isotopic excursions are labeled.

Bay records indicates that the nature of Holocene climate change was quite different between the tropics and the midlatitudes (Figure 10). The Cariaco record shows that the tropics were relatively wet during the early Holocene thermal maximum, while the mid-Atlantic region of the eastern United States was extremely dry (higher salinity) at this time. Conversely, the tropics became progressively drier during the late Holocene, whereas the midlatitudes became substantially wetter (lower salinity).

[40] Although it is not possible to compare individual decadal events because of the limits of the chronology, both records show evidence for multidecadal climate variability during the early and late Holocene. Moreover, large Cariaco titanium excursions during the Medieval Warm Period centered at $\sim 1000$ and 600 years B.P. indicate a shift toward wetter conditions at the same time the mid-Atlantic became much drier. Similarly, at least two major events punctuate the Little Ice Age between 500 and 100 years B.P. when the tropics and midlatitudes became drier and wetter, respectively. Thus the anticorrelation between precipitation patterns in the two regions holds at both millennial and centennial scales.

[41] Another climate time series is the Irish speleothem isotope record, which is influenced by regional atmospheric temperatures in the northeast Atlantic in addition to other factors such as the isotopic composition of precipitation and drip water [McDermott et al., 1999]. For the early Holocene, the speleothem and Chesapeake records do not show obvious similarities, except in the general sense that mean temperatures were at times relatively high in both regions (Figure 11). A better correspondence is seen during the late Holocene when 


\section{Early Holocene}
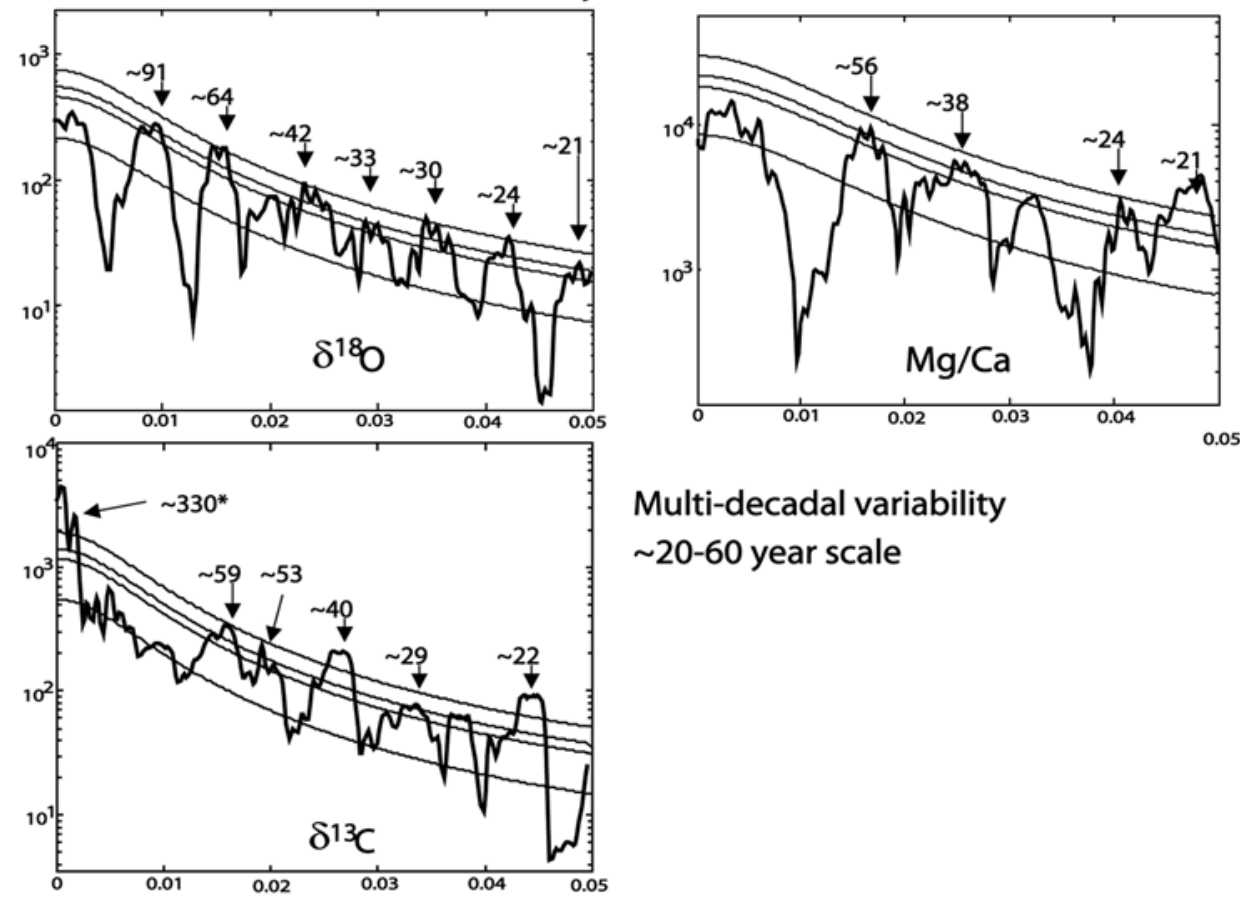

Multi-decadal variability 20-60 year scale
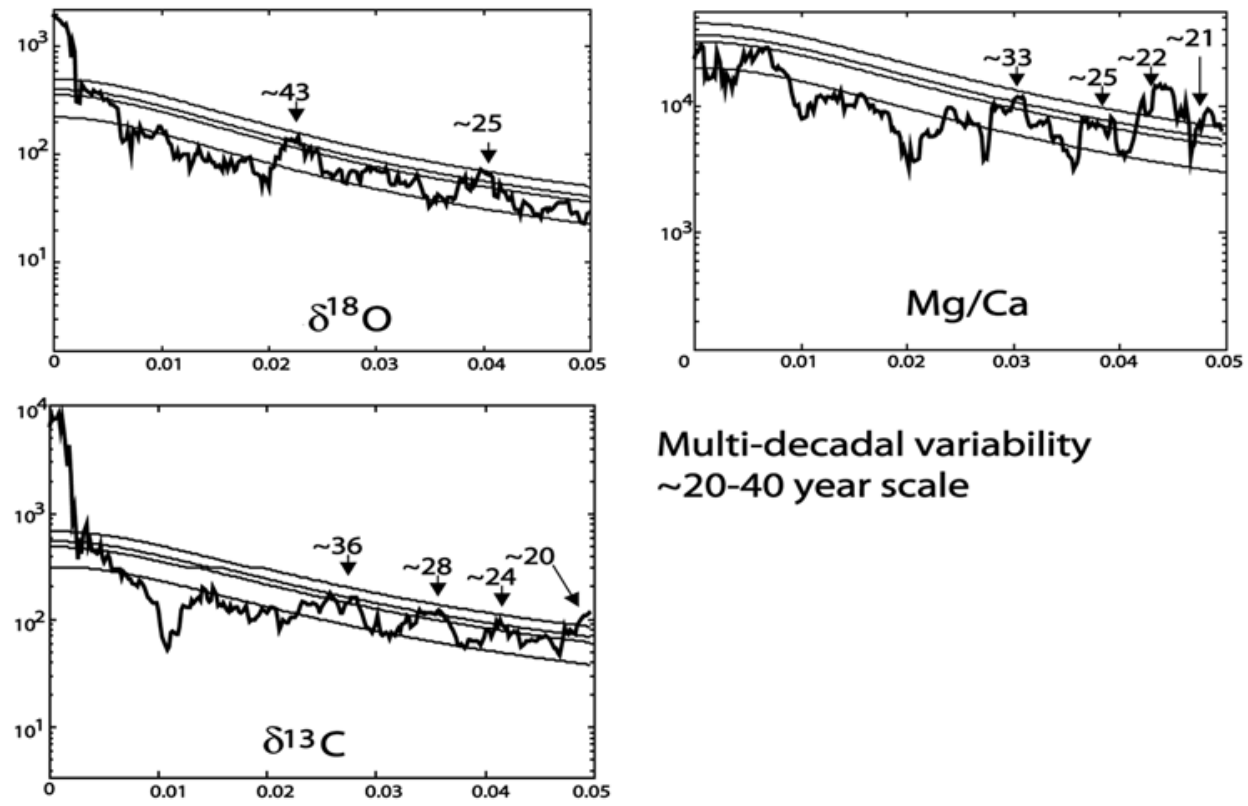

\section{Multi-decadal variability} 20-40 year scale

Figure 9. Early and late Holocene spectral peaks for carbon, oxygen, and $\mathrm{Mg} / \mathrm{Ca}$ data. Spectra are shown for frequencies $<0.05$ cycle per year $(>20$-year period) owing to the decadal low pass, the multitaper spectrum (and median, 90\%, 95\%, and 99\% confidence levels based on red noise assumption) for each series (frequency is in cycles/5 years). The bandwidth used for the latter is twice that for the former, owing to the roughly double length of the available series. Bold italicized peaks are significant at $99 \%$ level; standard type peaks at $95 \%$. The $X$ axis shows frequencies based on the convention that $f=0.5$ is a 10 -year period and $f=0.05$ is a 100 -year period. 


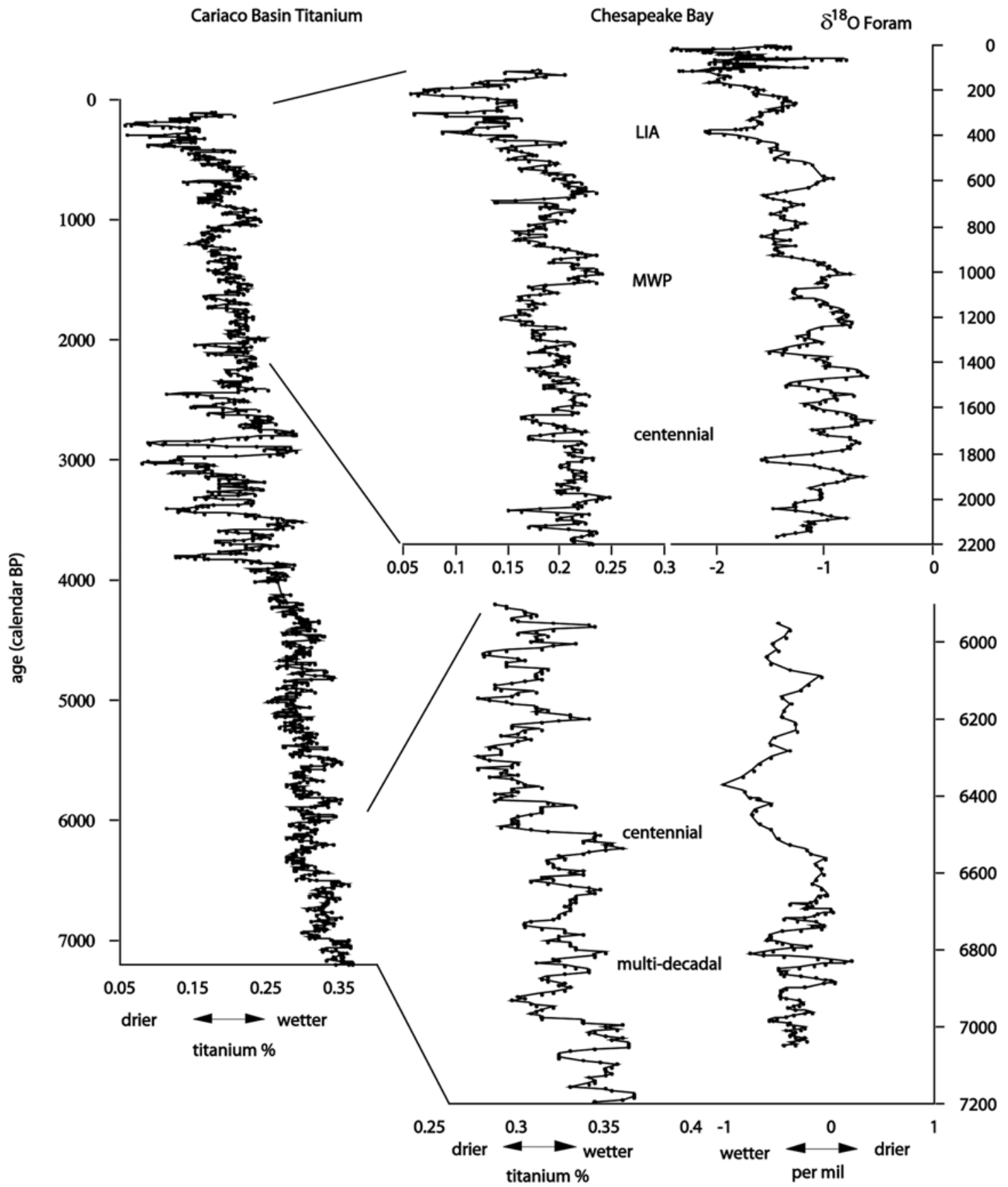

Figure 10. Comparison of Chesapeake paleoclimate record with titanium record from Cariaco Basin [Haug et al., 2001]. Intervals showing clear multidecadal and centennial isotopic excursions are shown, as are excursions during Medieval Warm Period and Little Ice Age. Curves are three-point moving averages.

relatively warm conditions existed $\sim 1200-1000$ years B.P. and during cool conditions at least twice during the Little Ice Age centered at 500 and 300 years B.P.

\section{Discussion}

[42] On the basis of the Cariaco Basin record of inferred precipitation and wind-driven upwelling, Haug et al. [2001] proposed that during the early Holocene thermal maximum, trade winds were relatively weaker and the ITCZ was in a more southerly position than during the late Holocene. Our stable isotope records suggest that the early Holocene ( $\sim 7000$ years B.P.) in the mid-Atlantic was significantly drier than during the late Holocene and thus support this hypothesis. Assuming the modern relationships between NAO-atmospheric and oceanic processes apply, such an 


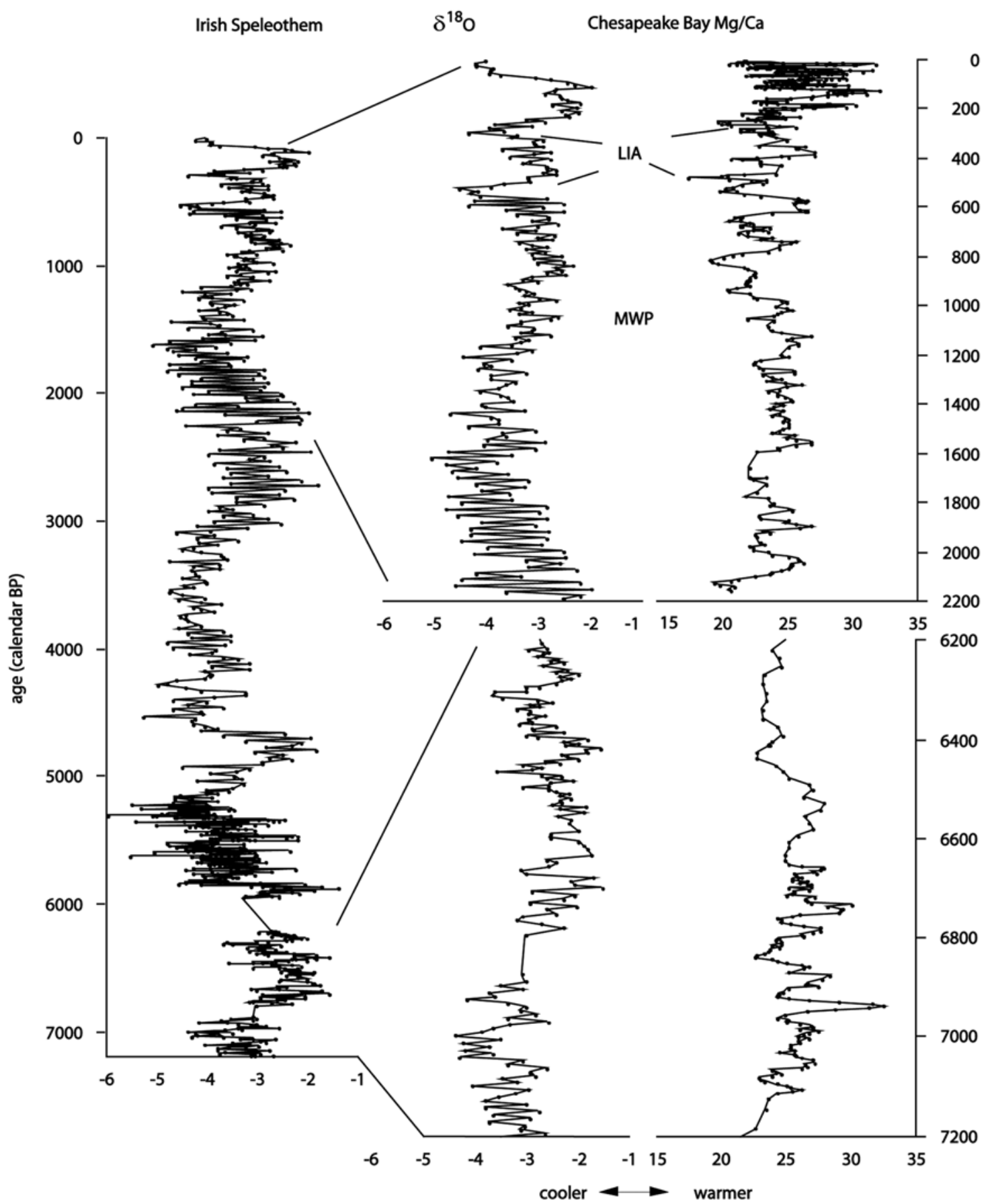

Figure 11. Comparison of Chesapeake $\mathrm{Mg} / \mathrm{Ca}$ paleotemperature record with Irish speleothem record [McDermott et al., 1999]. Speleothem isotopes are mainly influenced by temperature. Curves are threepoint moving averages.

early Holocene climate would be analogous to a persistent negative phase of the NAO manifested in weakened westerlies, decreased precipitation and fewer storm tracks along eastern North America. However, despite lower mean early Holocene precipitation in midlatitudes, the Chesapeake record indicates that decadal-scale variability was nonetheless prominent during the early Holocene in this part of the North Atlantic region. Similar modes of variability are also evident from well-dated lake records from New York [Kirby et al., 2002] and Greenland [Willemse and Törnqvist, 1999], and Irish speleothems [McDermott et al., 1999]. Thus one could argue that these reflect similar basin-wide climate processes during the early Holocene.

[43] Numerous paleoclimate records suggest that the midHolocene was a time of significant climate change in many parts of the world. In the Chesapeake Bay region, we 
observe a shift toward wetter conditions, while drier conditions developed in the tropics. As discussed above, this suggests that the western North Atlantic region also experienced major changes at millennial timescales. The most significant was a shift toward stronger trade winds and westerlies during the last few millennia.

[44] A complicating factor is the unknown contribution of ENSO to the mid-Atlantic paleoclimate record. It is plausible that the well-established shift in the strength and frequency of ENSO events sometime between 5000 and 3000 years B.P. [e.g., Rodbell et al., 1999; Clement et al., 2000; Sandweiss et al., 2001] may have affected extratropical regions in North American, as argued by Rittenour et al. [2000] and Menking and Anderson [2003], among others. We cannot evaluate this possibility until additional Holocene records become available, but at least in the modern system, ENSO is less important that the NAO in the North Atlantic region [Cassou and Terray, 2001; Hurrell et al., 2003].

[45] In addition to Holocene millennial-scale climate change, our results have bearing on the evolution of multidecadal NAO processes during the Holocene. It is well established that atmospheric processes drive oceanic SST over the North Atlantic over subdecadal timescales with no clear periodicity [see Wunsch, 1999; Czaja et al., 2003]. Oceanic feedbacks, including meridional overturning circulation occurring over multidecadal timescales, might also influence the long-term behavior of the NAO [Dickson et al., 1996; Hurrell and Dickson, 2004; Marshall et al., 2001; Visbeck et al., 2003]. While the exact mechanisms are complex and beyond the scope of this paper [see Latif, 1998; Eden and Willebrandt, 2001; Hurrell et al., 2003; Visbeck et al., 2003], these feedbacks might be manifested in quasiperiodic oscillations in temperature and precipitation similar to the those observed in Chesapeake Bay and elsewhere [e.g., Mann et al., 1995]. In fact, multidecadal to centennial temperature oscillations such as those observed here have been simulated as a response to solar forcing during Little Ice Age cooling that characterized the seventeenth century Maunder Minimum [Cubasch et al., 1997; Shindell et al., 2001; Waple et al., 2002]. If Holocene regional anomalies in eastern North America are confirmed by additional paleorecords as manifestations of larger-scale precipitation and oceanic anomalies, then we can hypothesize that low-frequency climate variability might be an inherent characteristic of the North Atlantic during the Holocene. Oscillations in Chesapeake Bay temperature are particularly noteworthy if they are caused by temperature anomalies in oceanic source water linked to NAO forcing of SSTs in the western North Atlantic [Visbeck et al., 2003].

[46] Finally, important questions remain regarding whether the unprecedented positive NAO values of the last few decades are related to anthropogenic forcing [Hurrell, 1995; Gillett et al., 2003]. The evidence presented here suggests that oxygen, carbon and $\mathrm{Mg} / \mathrm{Ca}$ excursions during the last century are among the most extreme in the Holocene. Similarly, Cook [2003] concluded that twentieth century NAO behavior is unusual though not necessarily unique based on comparisons with tree ring records of NAO variability in eastern North American and Europe going back to A.D. 1400. There is consequently a need for integrated paleoclimate reconstructions in regions sensitive to NAO forcing.

[47] Acknowledgments. We are grateful to Yvon Balut, Elsa Cortijo, and the crew of the Marion-Dufresne for efforts to core the shallow waters of Chesapeake Bay. Greg Wandless and Eric Tappa helped with the isotope analyses, Lisa Wiemer and Dan Dauer (Old Dominion University) helped with water sample collection, E. Klein provided access to the DCP. James Hurrell and Adam Phillips (NCAR) kindly provided NAO figures. D. Willard, H. Dowsett, J. Holmes, and an anonymous reviewer provided useful comments on the paper. M. E. M. was supported by the NOAA and NSF-supported Earth Systems History program.

\section{References}

Anderson, T. F., and M. A. Arthur (1983), Stable isotopes of oxygen and carbon and their application to sedimentologic and paleoenvironmental problems, in Stable Isotopes in Sedimentary Geology, edited by M. A. Arthur et al., SEPM Short Course, 10, 1-1-1-151.

Appenzeller, C., T. F. Stocker, and M. Anklin (1998), North Atlantic Oscillation dynamics recorded in Greenland ice cores, Science, 282, 446-448.

Austin, J. (2004), Estimating effective longitudinal dispersion in the Chesapeake Bay, Coastal Shelf Sci., 60, 359-368.

Baucom, P. C., J. F. Bratton, S. M. Colman, J. M. Moore, J. King, C. Heil, and R. Seal (2001), Selected Data for sediment cores collected in Chesapeake Bay in 1996 and 1998, U.S. Geol. Surv. Open File Rep., 01-194.

Boicourt, W. C., M. Kuzmic, and T. S. Hopkins (1999), The inland sea: Circulation of Chesapeake Bay and the northern Adriatic, in Ecosystems at the Land-Sea Margin: Drainage Basin to Coastal Sea, edited by T. C. Malone et al., Coastal Estuarine Stud., vol. 55, pp. 81 129, AGU, Washington, D. C.
Bratton, J. F., S. M. Colman, E. R. Thieler, and R. R. Seal II (2003a), Birth of the modern Chesapeake Bay estuary 7,400 to 8,200 years ago and implications for global sea-level rise, Geo Mar. Lett., 22, 188-197.

Bratton, J. F., S. M. Colman, and R. R. Seal II (2003b), Eutrophication and carbon sources in Chesapeake Bay over the last 2700 yr: Human impacts in context, Geochim. Cosmochim. Acta, 67, 1-18.

Brush, G. S. (1984), Patterns of recent sediment accumulation in Chesapeake Bay (VA, MD, U.S.A.) tributaries, Chem. Geol., 44, 227242.

Buzas, M. A. (1969), Foraminiferal species densities and environmental variables in an estuary, Limnol. Oceanogr., 14, 411-422.

Canuel, E. A. (2001), Relations between river flow, primary production and fatty acid composition of particulate organic matter in San Francisco and Chesapeake Bays: A multivariate approach, Org. Geochem., 32, 563583.

Cassou, C., and L. Terray (2001), Dual influence of Atlantic and Pacific SST anomalies on the
North Atlantic/Europe winter climate, Geophys. Res. Lett., 28, 3195-3198.

Chandler, G. T., D. F. Williams, H. J. Spero, and G. Xiaodong (1996), Sediment microhabitat effects on carbon stable isotopic signatures of microcosm-cultured benthic foraminifera, Limnol. Oceanogr., 41, 680-688.

Chapman, D. C., J. A. Barth, R. C. Beardsley, and R. G. Fairbanks (1986), On the continuity of mean flow between the Scotian Shelf and the Middle Atlantic Bight, J. Phys. Oceanogr. $16,758-772$.

Clement, A. C., R. Seager, and M. A. Cane (2000), Suppression of El Niño during the mid-Holocene by changes in the Earth's orbit, Paleoceanography, 15, 731-737.

Colman, S. M., and R. B. Mixon (1988), The record of major Quaternary sea-level changes in a large coastal plain estuary, Chesapeake Bay, eastern United States, Palaeogeogr. $\mathrm{Pa}$ laeoclimatol. Palaeoecol., 68, 99-116.

Colman, S. M., P. C. Baucom, J. F. Bratton, T. M. Cronin, J. P. McGeehin, D. Willard, and A. R. Zimmerman (2002), Radiocarbon dating, chronologic framework, and changes in accu- 
mulation rates of Holocene estuarine sediment from Chesapeake Bay, Quat. Res., 57, 58-70.

Cook, E. R. (2003), Multi-proxy reconstructions of the North Atlantic Oscillation (NAO) index: A critical review and a new well-verified winter NAO index reconstruction back to $\mathrm{AD}$ 1400, in The North Atlantic Oscillation: Climatic Significance and Environmental Impact, Geophys. Monogr. Ser., vol. 134, edited by J. W. Hurrell et al., pp. 63-79, AGU, Washington, D. C.

Cook, E. R., R. D. D'Arrigo, and K. R. Briffa (1998), A reconstruction of the North Atlantic Oscillation using tree-ring chronologies from North America and Europe, Holocene, 8, 917.

Cook, E. R., D. M. Meko, D. W. Stahle, and M. K. Cleaveland (1999), Drought reconstructions for the continental United States, J. Clim., 12, 1145-1162.

Cook, E. R., R. D. D'Arrigo, and M. E. Mann (2002), A well-verified multi-proxy reconstruction of the winter North Atlantic Oscillation index since AD 1400, J. Clim., 15, 17541764.

Cronin, T. M. (Ed.) (2000), Initial report on IMAGES V cruise of the Marion-Dufresne to the Chesapeake Bay June 20-22, 1999, U.S. Geol. Surv. Open File Rep., 00-306.

Cronin, T. M. (Ed.) (2004), Pocomoke Sound sedimentary and ecosystem history, U.S. Geol. Surv. Open File Rep., 04-1350.

Cronin, T. M., and C. Vann (2003), The sedimentary record of anthropogenic and climatic influence on the Patuxent Estuary and Chesapeake Bay ecosystems, Estuaries, 26, 196-209.

Cronin, T., D. Willard, A. Karlsen, S. Ishman, S. Verardo, J. McGeehin, R. Kerhin, C. Holmes, S. Colman, and A. Zimmerman (2000), Climatic variability in the eastern United States over the past millennium from Chesapeake Bay sediments, Geology, 28, 3-6.

Cronin, T. M., G. S. Dwyer, T. Kamiya, S. Schwede, and D. A. Willard (2003), Medieval Warm Period, Little Ice Age and 20th century temperature variability from Chesapeake Bay, Global Planet. Change, 36, 17-29.

Cronin, T. M., T. Kamiya, G. S. Dwyer, H. Belkin, C. D. Vann, S. Schwede, and R. Wagner (2005), Ecology and shell chemistry of Loxoconcha matagordensis, Palaeogeogr., Palaeoclimatol., Palaeoecol, 225, 14-67.

Cubasch, U., R. Voss, G. C. Hegerl, J. Wazskewitz, and T. J. Crowley (1997), Simulation of the influence of solar radiation variations on the global climate with an ocean-atmosphere general circulation model, Clim. Dyn., 13, $757-$ 767.

Cullen, H. M., R. D'Arrigo, E. Cook, and M. E. Mann (2001), Multi-proxy-based reconstructions of the North Atlantic Oscillation over the past three centuries, Paleoceanography, $15,27-39$.

Czaja, A., A. W. Robertson, and T. Huck (2003), The role of Atlantic ocean-atmosphere coupling in affecting North Atlantic Oscillation variability, in The North Atlantic Oscillation: Climatic Significance and Environmental Impact, Geophys. Monogr. Ser., vol. 134, edited by J. W. Hurrell et al., pp. 147-172, AGU, Washington, D. C

Delworth, T., and M. Mann (2000), Observed and simulated multi-decadal variability in the Northern Hemisphere, Clim. Dyn., 16, 661676.

Deser, C., and M. L. Blackmon (1993), Surface climate variations over the North Atlantic
Ocean during winter: 1900-1997, J. Clim., 6, 1743-1753.

Dickson, R. R., J. Zazier, J. Meincke, P. Rhines, and J. Swift (1996), Long-term co-ordinated changes in the convective activity of the North Atlantic, Prog. Oceanogr., 38, 241-295.

Dwyer, G. S., T. M. Cronin, and P. A. Baker (2002), Trace elements in marine ostracodes, in The Ostracoda: Applications in Quaternary Research, Geophys. Monogr. Ser., vol. 131, edited by J. A. Holmes and A. R. Chivas, pp. 205-225, AGU, Washington D. C.

Eden, C., and J. Willebrandt (2001), Mechanisms of interannual to decadal variability: Oceanic response to the North Atlantic Oscillation (1865-1997), J. Clim., 14, 2266-2280.

Ellison, R. L., and M. M. Nichols (1976), Modern and Holocene foraminifera in the Chesapeake Bay region, Marit. Sediments, 131-151, suppl. 1, part A

Gibson, J., and R. Najjar (2000), The response of Chesapeake Bay salinity to climate-induced changes in streamflow, Limnol. Oceanogr., $45,1764-1772$

Gillet, N. P., H. F. Graf, and T. J. Osborn (2003), Climate change and the North Atlantic Oscillation, in The North Atlantic Oscillation: Climatic Significance and Environmental Impact, Geophys. Monogr. Ser., vol. 134, edited by J. W. Hurrell et al., pp. 193-209, AGU, Washington, D. C

Gomez, B., L. Carter, N. A. Trustrum, A. S. Palmer, and A. P. Roberts (2004), El NiñoSouthern Oscillation signal associated with middle Holocene climate change in intercorrelated terrestrial and marine sediment cores, North Island, New Zealand, Geology, 32, 653-656.

Grossman, E. (1987), Stable isotopes in modern benthic foraminifera: A study of vital effect, J. Foraminiferal Res., 17, 48-61.

Haug, G. H., K. A. Hughen, D. M. Sigman, L. C. Peterson, and U. Röhl (2001), Southward migration of the intertropical convergence zone through the Holocene, Science, 293, 1304 1308

Hurrell, J. W. (1995), Decadal trends in the North Atlantic Oscillation regional temperatures and precipitation, Science, 292, 90-92.

Hurrell, J. W., and R. R. Dickson (2004), Climate variability over the North Atlantic, in Ecological Effects of Climate Variations in the North Atlantic, edited by N. C. Stenseth et al., pp. 15-31, Oxford Univ. Press, New York.

Hurrell, J. W., Y. Kushnir, G. Ottersen, and M. Visbeck (2003), An overview of the North Atlantic Oscillation, in The North Atlantic Oscillation: Climatic Significance and Environmental Impact, Geophys. Monogr. Ser., vol 134, edited by J. W. Hurrell et al., pp. 1-35, AGU, Washington, D. C.

Ingram, B. L., M. E. Conrad, and J. C. Ingle (1996), Stable isotope and salinity systematics in estuarine waters and carbonates: San Francisco Bay, Geochim. Cosmochim. Acta, 60, 455-467.

Jones, P. D., M. New, D. E. Parker, S. Martin, and I. G. Rigor (1999), Surface air temperature and its variations over the last 150 years, Rev. Geophys., 37, 173-199.

Kapala, A., H. Machel, and H. Flohn (1998), Behavior of the centres of action above the Atlantic since 1881. Part II: Associations with regional climate anomalies, Int. J. Climatol, $18,23-36$

Karlsen, A. W., T. M. Cronin, S. E. Ishman, D. A. Willard, C. W. Holmes, M. Marot, and R. Kerhin (2000), Historical trends in Chesapeake Bay dissolved oxygen based on benthic foraminifera from sediment cores, Estuaries, 23, 488-508.

Kerhin, R. T., C. Williams, and T. M. Cronin (1998), Lithologic descriptions of piston cores from Chesapeake Bay, Maryland, U.S. Geol. Surv. Open File Rep., 98-787.

Khim, B.-K., and D. E. Krantz (1996), Oxygen isotopic identity of the Delaware Coastal Current, J. Geophys. Res., 101(C7), 16,50916,514

Kirby, M. E., H. T. Mullins, W. P. Patterson, and A. W. Burnett (2002), Late GlacialHolocene atmospheric circulation and precipitation in the northeast United States inferred from modern calibrated stable oxygen and carbon isotopes, Geol. Soc. Am Bull., 114, 1326-1340.

Latif, M. (1998), Dynamics of interdecadal variability in coupled ocean-atmosphere models, J. Clim., 11, 602-624.

Luterbacher, J., D. Dietrich, E. Xoplaki, M. Grosjean, and H. Wanner (2004), European seasonal and annual temperature variability, trends and extremes since 1500, Science, 303, 1499-1503.

Mann, M. E., and J. Lees (1996), Robust estimation of background noise and signal detection in climatic time series, Clim. Change, 33, 409-445.

Mann, M. E., and J. Park (1993), Spatial correlations of interdecadal variation in global surface temperatures, Geophys. Res. Lett., 20, 1055 1058

Mann, M. E., J. Park, and R. S. Bradley (1995), Global interdecadal and century-scale climate oscillations during the past five centuries, Nature, 378, 266-270.

Marshall, J., H. Johnson, and J. Goodman (2001), A study of the interaction of the North Atlantic Oscillation with the ocean circulation, J. Clim., 14, 1399-1421.

McCorkle, D. C., L. D. Keigwin, B. H. Corliss, and S. R. Emerson (1990), The influence of microhabitats on the carbon isotopic composition of deep-sea benthic foraminifera, Paleoceanography, 5, 161-185.

McDermott, F., D. P. Mattey, and C. Hawkesworth (1999), Centennial-scale Holocene climate variability revealed by high-resolution speleothem $\delta^{18} \mathrm{O}$ record from SW Ireland, Science, 294, 1328-1331.

Menking, K. M., and R. Y. Anderson (2003), Contributions of La Niña and El Niño to middle Holocene drought and late Holocene moisture in the American southwest, Geology, 31, 937-940.

Montroy, D. L. (1997), Linear relation of central and eastern North American precipitation to tropical Pacific sea surface temperature anomalies, J. Clim., 10, 541-558.

Najjar, R. G. (1999), The water balance of the Susquehanna River Basin and its response to climate change, J. Hydrol., 219, 7-19.

Riedinger, M. A., M. Steinitz-Kannan, W. M Last, and M. Brenner (2002), A $\sim 6100{ }^{14} \mathrm{C}$ yr record of El Niño activity from the Galapagos Islands, J. Paleolimnol., 27, 1-7.

Rittenour, T. M., J. Brigham-Grette, and M. E. Mann (2000), El Niño-like climate teleconnections in New England during the late Pleistocene, Science, 288, 1039-1042.

Rodbell, D. T., G. O. Seltzer, D. M. Anderson, M. B. Abbott, D. B. Enfield, and J. H. Newman (1999), An 15,000-year record of El Niñodriven alluviation in southwestern Ecuador, Science, 282, 516-520. 
Romanek, C. S., E. L. Grossman, and J. W. Morse (1992), Carbon isotopic fractionation in synthetic aragonite and calcite: Effects of temperature and precipitation rate, Geochim. Cosmochim. Acta, 56, 419-430.

Ropelewski, C. F., and M. S. Halpert (1986), North American precipitation and temperature patterns associated with the El Niño/Southern Oscillation (ENSO), Mon. Weather Rev., 11, $2352-2362$.

Rosanski, K., L. Araguas-Araguas, and R. Gonfiantini (1993), Isotopic patterns in modern global precipitation, in Climate Change in Continental Isotopic Records, edited by P. K. Swart et al., pp. 1-36, Geophys. Monogr. Ser., vol. 78, AGU, Washington, D. C.

Sandweiss, D. W., K. A. Maasch, R. L. Burger, J. B. Richardson III, H. B. Rollins, and A. Clement (2001), Variation in Holocene El Niño frequencies: Climate records and cultural consequences in ancient Peru, Geology, 7, 603-606.

Schlesinger, M. E., and N. Ramankutty (1994), An oscillation in the global climate system of period 65-70 years, Nature, 367, 723-726.

Schöne, B. R., W. Oschmann, J. Rössler, A. D. Freyre Castro, S. D. Houk, I. Krönicke, W. Dreyer, R. Janssen, H. Rumohr, and E. Dunca (2003), North Atlantic Oscillation dynamics recorded in shells of a long-lived bivalve mollusk, Geology, 31, 1037-1040.

Schubel, J. R., and D. W. Pritchard (1986), Responses of upper Chesapeake Bay to variations in discharge of the Susquehanna River, Estuaries, 9, 236-249.

Shindell, D. T., G. A. Schmidt, M. E. Mann, D. Rind, and A. Waple (2001), Solar forcing of regional climate change during the Maunder minimum, Science, 294, 2149-2152.

Spiker, E. (1978), The behavior of ${ }^{14} \mathrm{C}$ and ${ }^{13} \mathrm{C}$ in estuarine water-Effects of in situ $\mathrm{CO}_{2}$ production and atmospheric change, Radiocarbon, 22, 647-654.

Stuiver, M., P. J. Reimer, E. Bard, J. W. Beck, G. S. Burr, K. A. Hughen, B. Kromer, G. McCormac, J. van der Plicht, and M. Spurk (1998),
INTCAL98 radiocarbon age calibration, 24,000-0 cal BP, Radiocarbon, 40, 1041 1083

Thomas, E., T. Gapotchenko, J. C. Varekamp, E. L. Mecray, and M. R. Buchholtz ten Brink (2000), Benthic foraminifera and environmental changes in Long Island Sound, J. Coastal Res., 16, 641-655.

Vann, C., T. M. Cronin, and G. S. Dwyer (2004), Population ecology and shell chemistry of a phytal ostracode (Loxoconcha matagordensis) in the Chesapeake Bay watershed, Mar. Micropaleontol., 53, 261-277.

Vega, A. J. C. H. Sui, and K. M. Lau (1998), Interannual to interdecadal variations of the regionalized surface climate of the United States and relationships to generalized flow parameters, Phys. Geogr., 19, 271-291.

Vega, A. J., R. V. Rohli, and C. H. Sui (1999), Climatic relationships to Chesapeake Bay salinity during Southern Oscillation extremes, Phys. Geogr. 20, 468-490.

Visbeck, M., E. P. Chassignet, R. G. Curry, T. L. Delworth, R. R. Dickson, and G. Krahmann (2003), The ocean's response to North Atlantic Oscillation variability, in The North Atlantic Oscillation: Climatic Significance and Environmental Impact, Geophys. Monogr. Ser, vol. 134, edited by J. W. Hurrell et al., pp. 113-146, AGU, Washington, D. C

Vogt, P., J. P. Halka, R. A. Hagen, and T. M. Cronin (2000), Geophysical environment in Chesapeake Bay: Marion-Dufresne sites MD03-2205, 2206, 2208, in Initial Report on IMAGES V Cruise of Marion-Dufresne to Chesapeake Bay June 20-22, 1999, edited by T. M. Cronin, U. S. Geol. Surv. Open File Rep., 00-306, 18-31.

Waple, A., M. E. Mann, and R. S. Bradley (2002), Long-term patterns of solar irradiance forcing in model experiments and proxy-based surface temperature reconstructions, Clim. Dyn., 18, 563-578.

Willard, D. A., T. M. Cronin, and S. Verardo (2003), Late Holocene climate and ecosystem variability from Chesapeake Bay sediment cores, Holocene, 13, 201-214.

Willard, D. A., C. E. Bernhardt, D. A. Korejwo, and S. R. Meyers (2005), Impact of millennialscale Holocene climate variability on eastern North American terrestrial ecosystems: Pollenbased climatic reconstruction, Global Planet Change, 47, 17-35.

Willemse, N. W., and T. E. Törnqvist (1999), Holocene century-scale temperature variability from West Greenland lake records, Geology, 27, $580-584$.

Wunsch, C. (1999), The interpretation of short climate records with comments on the North Atlantic Oscillation and Southern Oscillation, Bull. Am. Meteorol. Soc., 80, 245-255.

Yarnal, B., and D. J. Leathers (1988), Relationships between interdecadal and interannual climate variations and their effect on Pennsylvania climate, Ann. Assoc. Am. Geogr. $78,624-641$.

Zimmerman, A. R., and E. A. Canuel (2000), A geochemical record of eutrophication and anoxia in Chesapeake Bay sediments: Anthropogenic influence on organic matter composition, Mar. Chem., 69, 117-137.

T. M. Cronin, C. Saenger, R. R. Seal II, and C. Vann, MS 926A, U.S. Geological Survey, Reston, VA 20191, USA. (tcronin@ usgs.gov)

G. S. Dwyer, Nicholas School of the Environment, Earth and Ocean Sciences, Duke University, Durham, NC 27708, USA.

M. E. Mann, Department of Meteorology, Pennsylvania State University, University Park, PA 16802, USA.

R. Thunell, Department of Geological Sciences, University of South Carolina, Columbia, SC 29208, USA 